\title{
BİST Pay Piyasasında Açı̆̆a Satış Yasağı ve COVID-19 Düzenlemelerinin Piyasa Etkinliği Üzerindeki Etkisi
}

\author{
Sinan AYTEKİN ${ }^{1}$, Nida ABDİOĞLU² ve Arif SEZGİN ${ }^{3}$
}

Öz

Bu çalışmada ilk olarak 28 Şubat 2020 tarihinde Sermaye Piyasası Kurulunun (SPK) Borsa İstanbul (BİST) pay piyasalarında açığa satışı yasakladığını duyurmasının BIST-30 endeksi şirketleri üzerindeki etkisi incelenmiştir. İkinci olarak ise COVID-19 salgınının ve bunu izleyen BİST piyasa düzenlemelerinin BİST-30 endeksi şirketleri üzerindeki etkisi incelenmiştir. 11 Mart 2020 tarihinde Türkiye'de ilk COVID-19 vakası raporlanmış ve aynı gün Dünya Sağlık Örgütü (DSÖ) virüs salgınını pandemi olarak ilan etmiştir. Piyasalarda oluşan tedirginlik nedeniyle Borsa İstanbul Genel Müdürlüğü 12 Mart günü pay piyasasında devre kesici tetikleme oranı ile günlük fiyat değişim limitlerinde değişikliğe gideceğini duyurmuş ve 13 Mart günü yeni oranları uygulamaya koymuştur. Olay etüdü yöntemi kullanılarak, 28 Şubat ve 13 Mart günleri 2 ayrı olay günü olarak belirlenerek her iki olayın da BİST-30 endeksi şirketleri üzerindeki etkisi incelenmiştir. İlk olay incelendiğinde açığa satış yasağ1 sonrasında endeks ve pay senetlerinin değer kaybettiği görülmüştür. İkinci olarak fiyat marj1 ve devre kesici tetikleme oranı düzenlemeleri sonrasında anormal getirinin pozitif olduğu bulunmuştur. Dolayısıla bu uygulamanın piyasada fiyat dalgalanmaları ve fiyat oluşumu etkinliği açısından faydalı olduğu sonucuna varılmıştır.

Anabtar Kelimeler: Açığa Satış, Fiyat Marjı, Devre Kesici, COVID-19, Borsa İstanbul

\section{The Impact of Short Selling Bans and COVID-19 Regulations of Borsa Istanbul Equity} Market on Market Efficiency

\begin{abstract}
This study firstly examines the impact of the announcement of short selling ban of Borsa İstanbul (BIST) in 28 Feb 2020 on BIST-30 indices firms. Secondly, the effect of COVID-19 epidemic and following market corrections on BIST-30 indices firms are investigated. Turkey reported the first COVID-19 case on 11 March 2020 and World Health Organization announced the virus epidemic as pandemic the same day. Because of the uneasiness in the markets on 12 March, head office of Borsa Istanbul announced that they would change the circuit breaker rate and daily price change limit. Following this announcement, they started to apply new rates on 13 March. By using event study methodology and determining 28 February and 13 March as two different event days, this study examines the impact of these two events on BIST-30 indices firms. According to the empirical results, indices and shares lose value after short sale ban in the first event. In the second event it is found that after the regulations in price margin and breaker rate, abnormal return turns out to be positive. Thus, this regulation is useful for the effectiveness of price fluctuations and price formation in the market.
\end{abstract}

Key Words: Short Selling, Price Margin, Circuit Breaker, COVID-19, Borsa Istanbul

\section{Atıf İçin / Please Cite As:}

Aytekin, S., Abdioğlu, N. ve Sezgin, A. (2021). BİST pay piyasasında açı̆̆a satış yasağı ve COVID-19 düzenlemelerinin piyasa etkinliği üzerindeki etkisi. Manas Sosyal Araștırmalar Dergisi, 10(4), 2433-2448.

Geliş Tarihi / Received Date: 29.06.2020

Kabul Tarihi / Accepted Date: 06.08.2021

\footnotetext{
${ }^{1}$ Doç. Dr. - Balıkesir Üniversitesi İktisadi ve İdari Bilimler Fakültesi, saytekin@balikesir.edu.tr

(iD) ORCID: 0000-0003-1502-2643

2 Doç. Dr. - Bandırma Onyedi Eylül Üniversitesi İktisadi ve İdari Bilimler Fakültesi, nabdioglu@bandirma.edu.tr

(D) ORCID: 0000-0002-8498-9893

3 Arş. Gör. - Balıkesir Üniversitesi İktisadi ve İdari Bilimler Fakültesi, arif.sezgin@balikesir.edu.tr

(D) ORCID: 0000-0002-3381-6458
} 


\section{Giriş}

BİST-100 endeksi 2019 yılını 114.424,96 puandan kapatmış, 2020 yılında yükselişine devam ederek 2020 yılı Ocak ayında 120.000 puanın üzerine çıkmıştır. 27 Şubatta İdlip’te rejim güçleri tarafindan Türk askerlerine yönelik hava saldırısı düzenlenmesi sonrasında bir önceki gün 115.000 seviyelerinde olan endeks iki gün içinde 105.000 seviyelerine kadar geri çekilmiştir. Bu noktada SPK, 28 Şubatta BİST pay piyasalarında açığa satışı yasakladığını duyurarak aynı gün uygulamaya koymuştur. Açığa satış yasağ1 uygulaması devam ederken COVID-19 salgınının dünya piyasalarında yarattığı endişe de gerek yatırımcılar gerekse de yasal otorite tarafindan takip edilmeye devam edilmiştir. Türkiye'de 11 Mart tarihinde ilk koronavirüs vak'asının raporlanması ve aynı gün DSÖ'nün virüs salgınını pandemi olarak ilan etmesi tüm piyasalarda olduğu gibi BİST’te de tedirginliğe neden olmuştur. Borsa İstanbul Genel Müdürlüğü, 12 Mart günü pay piyasasında devre kesici tetikleme oranı ile günlük fiyat değişim limitlerinde değişikliğe gideceğini duyurarak 13 Mart günü yeni oranları uygulamaya koymuştur. Bu düzenlemenin temel amacı volatiliteyi azaltarak piyasada olası panik satıslarıyla oluşabilecek kayıpları engellemektir. BIST-100 endeksi, 13 Mart günü bir önceki güne göre yaklaşık 2.000 puanlık yükselişle 95.000 puan seviyelerinden kapanmıştır. Devam eden açığa satış yasağı uygulaması ile devre kesici ve fiyat marjı kısıtlamalarına rağmen 23 Mart’a kadar düşüş trendi devam etmiştir. 23 Mart günü BİST-100 endeksi Ocak ayının başından bu yana gördüğü en düşük seviye olan 84.000 puan seviyelerinden kapanmıştır. COVID-19 salgını nedeniyle gelişmiş ülkelerin de ekonomilerini kapatmaları nedeniyle büyük merkez bankalarından peş peşe gelen varlık alımı ve parasal genişleme adımları finansal piyasalarda karşılık bulmuştur. Bu gelişmelerin BİST’te de fiyatlanmaya başlanmasıyla beraber endeks Nisan ay1 sonunda yeniden 100.000 bin seviyelerine yükselmiştir.

Açığa satış, yatırımcının sahip olmadığı menkul kıymetleri satması ya da satışı için emir vermesi olarak tanımlanabilir (Abdioğlu ve Aytekin, 2019, s. 2083). Burada yatırımcının amacı menkul kıymeti daha sonra daha düşük fiyattan alarak fiyat düşüşünden kar elde etmektir. Açığa satışın finansal piyasalarda manipülasyona neden olmasından dolayı piyasada açığa satışın yasaklanması sıkça rastlanan bir durumdur. Özellikle 2008 yılı finansal krizinden sonra açığa satış işlemleri önem kazanmıştır. Finansal krizlere, sermaye piyasalarını düzenleyen otoriteler tarafından açığa satışı yasaklayarak ya da kısıtlayarak cevap verildiği görülmüştür (Beber ve Pagano, 2013, s. 343). Hükümetler, piyasa düzenleyiciler ve medya açığa satış yapanları piyasadaki düşüşlerin sebebi olarak gösterirken, diğer yandan bir başka görüşe göre açığa satış yanlış fiyatlamayı düzeltmekte ve piyasa etkinliğine katkıda bulunmaktadır (Sobacı vd., 2014, s. 22). Literatürdeki bir görüşe göre de açığa satış yasaklanı sonrası piyasadaki likidite azalır, arbitrajcılar piyasadan çekilir, pay senetleri fazla değerlenir ve piyasada fiyat etkinliği bozulur.

Diğer yandan uluslararası piyasa getirilerinde etkili olan güncel konulardan biri de pandemidir. Özellikle 11 Mart 2020 tarihi itibariyle DSÖ'nün COVID-19 kaynaklı pandemi ilan etmesi ile birlikte finansal piyasalar etkilenmiştir ve etkileri halen devam etmektedir. COVID-19'dan sonra dünya borsalarının genelinde pay fiyatlarında düşüşler görülmüşs ve bu durum dünya ekonomisini etkilemiştir (Sansa, 2020, s. 30). Birçok sektörün yapısı bu pandemiden dolayı bozulmuş ve dolayısıyla isslem hacimlerinde düşüşler meydana gelmiştir. Örneğin, Nissan, Toyota, General Motors, Honda, Renault ve Peugeot gibi firmalar Çin'deki üretimlerini durdurmuşlardır. Ayrıca birçok ülke Çin'den yaptıkları ithalat oranlarını düşürmüştür (Zeren ve Hizarc1, 2020, s. 79). Dolayısıyla COVID-19 pandemisi bir çeşit sistematik risk olarak görülmekte ve bu riskin piyasalar üzerindeki etkisinin araştırılmasının önemli olduğu belirtilmektedir (Sharif, 2020, s. 4). Bu çalışma ile henüz açığa satış yasağı kaldırılmamışken devamında gelen COVID-19 pandemisine piyasanın verdiği tepkinin ölçülmesi hedeflenmektedir. Bu nedenle de piyasa katılımcıları için önemli sonuçlar içermektedir. Ortaya koyduğu bulgular açısından da literatüre katkı sağlayacağı düşünülmektedir.

Bu çalışmada, iki ayrı olayın BİST-30 endeksindeki şirketlerin pay senedi getirileri üzerindeki etkisi araştırılmıştır. İlk olay SPK'nın 28 Şubat 2020 tarihinde BİST pay piyasalarında açığa satışı yasakladığını duyurmasıdır. Bu açığa satış yasağında Suriye'nin İdlip şehrinde Türk askerlerinin şehit düşmesi etkili olmuştur. İkinci olay tarihi ise 13 Mart 2020 olarak kabul edilmiştir. Bu olay tarihinin seçilmesinde hem 11 Mart 2020 tarihinde DSÖ'nün virüs salgını için pandemi ilan etmesi hem de virüs salgını sonrası BİST Genel Müdürlüğü tarafından alınan kararlar etkili olmuştur. BİST Genel Müdürlüğü Yıldız Pazar ve Ana Pazar tüm gruplarında işlem gören paylarda uygulanan fiyat marjının \%10'a düşürülmesine, Yıldız Pazar ve Ana Pazar tüm gruplarında işlem gören paylarda uygulanan devre kesici tetikleme oranının \% $\% 5^{\prime} \mathrm{e}$ düşürülmesine, Yıldız Pazar ve Ana Pazarda işlem gören paylarda uygulanan devre kesici sonrası emir toplama süresinin 30 dakika olarak uygulanmasına karar vermiş ve bunları 13 Mart 2020 tarihinde uygulamaya başlamıştır. 


\section{Literatür Taraması}

Uluslararası literatürde açığa satışa ilişkin kararların finansal piyasalara etkilerini inceleyen çalışmalara rastlamak mümkündür. Gerek piyasa etkinliği gerekse piyasa getirisinin ve volatilitesinin açığa satışa ilişkin kararlardan etkilendiği görülmektedir. Fakat ulusal çalışmaların bu konuda sınırlı olduğu anlaşılmaktadır. Borsa İstanbul üzerine yaptıkları çalışmalarında Çankaya vd. (2012) diğer çalışmalardan farklı olarak açığa satışın günlük volatilite yerine gün içi volatilite üzerindeki etkisini araştırmışlardır. Analiz sonuçları borsada yapılan açığa satış faaliyetlerinin pay senedi volatilitelerini azalttığını göstermektedir. Diğer yandan Sobac1 vd. (2014) Borsa İstanbul'daki artan açı̆̆a satış hacminin likidite, volatilite ve piyasa getirileri üzerindeki etkisini inceledikleri çalışmalarında, artan açı̆̆a satış hacminin likiditeyi artırdığı, volatiliteyi ise azalttı̆̆1 sonucuna varmışlardır. Yapılan analiz sonuçlarına göre açığa satışın pay fiyatlarındaki aşırı değerlemeyi önleyerek piyasa etkinliğine katkıda bulunduğu görülmektedir. Ayrıca 2008 finansal krizinde de açığa satış aktivitelerinin devam etmesinin piyasa kalitesini artırdığı sonucuna varılmıştır. Yani açığa satış için yapılan herhangi bir yasaklamanın piyasa kalitesini kötü yönde etkilediği ve finansal istikrarı zedelediğini belirtmişlerdir.

Uluslararası literatüre bakıldığında ise açığa satışın gerek ABD gerekse Avrupa borsaları üzerindeki etkisinin araştırıldığı görülmektedir. Açığa satış yasaklarının piyasa üzerindeki etkisini inceleyen çalışmalardan biri olan Autore vd. (2011) 2008'deki açığa satış yasağının ABD'deki finansal payların getirileri üzerindeki etkisini analiz etmişlerdir. Yasağın etkisinin firmanın likiditesine bağlı olduğunu bulmuşlardır. Daha fazla likidite azalışına sahip olan firmaların açığa satış yasağı sonucunda daha fazla negatif fiyat etkileri gösterdiklerini tespit etmişlerdir. Ayrıca yasaklanan pay senetlerinin pozitif anormal getiriye sahip oldukları görülmektedir. Diğer bir çalışmada Boehmer vd. (2013), ABD Menkul Kiymetler ve Borsa Komisyonu'nun (Securities and Exchange Commission-SEC) 2008 yllındaki açığa satış yasağ1 kararının piyasa üzerindeki etkisini araştırmışlardır. Bu çalışmada da açığa satış yasağının etkisinin firmaya özgü karakteristiklere bağlı olduğu varsayılmıştır. Bu karakteristik özellik Autore vd.'de (2011) likidite iken Boehmer vd.'de (2013) firma büyüklügüdür. Yasağın etkisinin daha çok büyük firmalarda görüldüğü sonucuna varılmıştır. Küçük sermayeli firmaların çoğunun etkilenmediği fakat büyük firmaların piyasa kalitelerinin kötüleştiği görülmüştür. Daha önceden açığa satış yasağı olan firmaların da yeni yasak sonucu piyasa kalitelerinde daha az düşüş görülmüştür. Bir başka çalışmada Beber ve Pagano (2013), Ocak 2008Haziran 2009 arasında 30 ülkeden 16491 pay senedinin günlük verisi ile bu dönemde yapılan açığa satış yasaklarının etkilerini araşı̧ımışlardır. Kriz sırasında uygulanan açığa satış yasağının likiditeyi olumsuz yönde etkilediği sonucuna varılmıştır. Aksine açığa satış ilanının piyasa likiditesini artırdığı bulunmuştur. Likidite olumsuzluğundan küçük sermayeli firmaların daha çok etkilendiği görülmüştür. Diğer yandan Li vd. (2018), Çin'in 2010 yılında belirli pay senetleri için uyguladığı açığa satış yasağının pay senedi fiyat etkinliğine ve likiditesine etkisini araştırmıştır. Açığa satış yasağının uygulanmasının pay senedinin fiyat etkinliğini ve likiditesini artırdığını bulmuşlardır. Sonuç olarak gelişmekte olan bir ülkede açığa satışın varlık fiyatlarını dengelediği, likiditeyi artırdığı ve dolayısıyla piyasa kalitesini artırdığı sonucuna varılmıstır.

Bohl vd. (2016) ise açığa satış yasağının Alman firmalarının pay senedi volatiliteleri üzerindeki etkisine bakmıştır. Açığa satış yasağı uygulanan pay senetlerinin volatilitelerinde artış bulunmuştur. Yine volatilite üzerine çalışma yapan Baklacı vd. (2016), Birleşik Devletler finansal piyasası için açığa satış faaliyetleri ve pay senedi volatilitesi arasındaki nedensellik ilişkisine bakmışlardır. Yapılan analizler sonucu açı̆̆a satış faaliyetleri ve volatilite arasında çift yönlü nedensellik bulunmuştur. Bu sonuç hem her bir pay senedi için hem de tüm piyasa için geçerlidir. Açığa satış faaliyetlerinin volatiliteyi artırdığını ve düzensiz piyasada açığa satış faaliyetlerinin arttığını bulmuşlardır. Ayrıca Baidoo (2019), ABD'deki açığa satış faaliyetlerinin volatiliteye etkisini inceleyerek finansal sektördeki açığa satışın volatiliteye etkisinin önemli derecede olduğunu bulmuşlardır. Henry ve McKenzie (2006) Hong Kong borsası üzerine, Jung vd.'nin (2013) Kore borsası üzerine, Mertzanis’in (2015) Atina borsası üzerine yaptıkları çalışmalarında, açığa satış işlemlerinin volatilite üzerinde etkisinin olduğu görülmüştür.

Açığa satış yasaklarının getiri üzerindeki etkisini araştıran çalışmalara da rastlamak mümkündür. Ebrahimnejad ve Hosainzade (2019), Miller’in (1977) savunduğu açığa satış kısıtlamalarının kaldırılmasının negatif getiriyle sonuçlanacağı görüşünü doğrulamışlardır. Bunda da kötümser yatırımcıların bilgilerini fiyatlara yansıtmalarının etkili olduğu düşünülmüştür. Miller (1977), açığa satış yasağının bir pay senedinin fazla değerlenmesi ile sonuçlandığını savunmaktadır. Morck vd. (2000) açığa satış yasaklarının kaldırılmasının, arbitrajcıların yanlış fiyatlamayı düzenlemesini kolaylaştıracağını ve firma hakkındaki bilginin fiyatlara yansıyacağını savunmaktadırlar. Böylece açığa satış işlemleri fiyat etkinliğini artıracaktır. 
Bris vd. (2007) ise 46 borsadaki açığa satış yasaklarını inceledikleri çalışmalarında, açığa satışa izin verilen piyasalarda fiyatın negatif bilgiyi daha hızlı yansıttığını bulmuşlardır. Ofek ve Richardson (2003), DotCom krizi esnasında yapılan açı̆̆a satış yasaklarının pay senedi getirilerini azalttığını göstermişlerdir. Boehmer vd. (2013) ise pay senedi fiyatlarının açığa satış yasağından etkilenmediğini savunmaktadırlar. Benzer şekilde Marsh ve Payne (2012) 2008 yllında uygulanan açığa satış yasağının Birleşik Krallık pay senedi piyasaları üzerindeki etkisine bakmışlardır. Finansal piyasalarda yasak sonrası herhangi bir değişiklik olmadığını görmüşlerdir. Piyasa kalitesi indikatörlerinin Eylül başlanında kötüleştiğini fakat bu kötüleşmenin sadece finansal şirketler için değil tüm şirketler için geçerli olduğunu belirtmişlerdir. İşlem maliyeti ve işlem hacimlerinin ise tüm şirketler için arttı̆̆ını tespit etmişlerdir.

COVID-19'un piyasa üzerindeki etkisini araştıran çalışmalara bakıldığında ise daha çok uluslararası alanda çalışmalar yapıldığ1 görülmüştür. COVID-19'un pay senedi getirileri ve volatiliteleri üzerindeki etkilerini araştıran çalışmalar mevcuttur. Al-Awadhi vd. (2020) COVID-19'un Çin borsası üzerindeki etkisini araştırmışlardır. Hang Seng Endeksi ve Şangay Kompozit Endeksindeki şirketleri ele almışlardır. Yaptıkları panel veri analizi sonucunda her iki endeks için de pay senedi getirilerinin hem vak'a sayısındaki günlük büyüme ile hem de COVID-19'un yol açtığ ölümlerin günlük büyüme oranı ile negatif ilişkili olduğunu bulmuşlardır. Al-Awadhi vd. (2020) ayrıca farklı sektörler için getirileri de incelemişlerdir. Yaptıkları analiz sonuçlarına göre bilişim teknolojisi ve tıbbi üretim sektörlerinin COVID-19 süresince piyasaya göre daha iyi performans gösterdiklerini tespit etmişlerdir. Fakat içecek, hava taşımacıllğı, deniz ulaşımı, karayolu taşımacilı̆̆ sektörlerinin COVID-19 süresince piyasadan daha kötü performansa sahip olduklarını bulmuşlardır. Diğer bir çalışmada Onali'nin (2020) COVID-19 ABD borsalarının getiri ve volatiliteleri üzerindeki etkisini araştıran ilk çalışma olduğunu iddia etmektedir. 31 Mart 2020 itibariyle en az 1.000 adet COVID-19'a bağlı ölümün olduğu ülkeleri ele almıştır. Bu ülkeler; İtalya, İspanya, Çin, ABD, Fransa, İran ve Birleşik Krallıktır. Çin'deki birkaç raporlanmış vak'a dışında ABD görülen vak'a sayısındaki artış ya da vak'a kaynaklı ölümlerin ve yllın ilk üç ayındaki COVID-19 vak'alarından etkilenen ülkelerin, ABD borsa getirileri üzerinde bir etkiye yol açmadıklarını tespit etmiştir. Yapılan VAR model analizlerine göre Fransa ve İtalya'daki ölümlerin Dow Jones getirileri üzerinde negatif, VIX üzerinde ise pozitif etkisi olduğu sonucuna varmiştır.

Baker vd. (2020) COVID-19'un şu ana kadar ABD borsasında volatiliteyi en çok etkileyen enfeksiyon hastalığ1 olduğunu belirtmektedir. Öncelikle 1900’lü yılların başına kadar herhangi bir pandeminin piyasaları etkileyip etkilemediğini araştırmışlardır. COVID-19'un ABD borsasında hareketliliğe neden olduğunu belirtmişlerdir. 24 Şubat-24 Mart 2020 tarihleri arasındaki 22 işlem gününde 18 piyasa yükselişi (market jump) olduğunu göstermişlerdir. Geçmişte bu sayıda yükselişe aynı sayıda işlem günü için rastlanmamıştır. Yükseliş sıklı̆̆ının 1900 yllından beri ortalama yükselişten 23 kere ile en yüksek seviyede olduğunu bulmuşlardır. Ayrıca COVID-19'un piyasa volatilitesine etkisini incelemişler ve volatilitenin geçmiş volatilitelerle karşılaştırllinca en yüksek seviyelerin birinde olduğunu göstermişlerdir. Diğer yandan Ding vd. (2020) 56 ülkeden 6000 şirketin 2020 yilının ilk çeyreğindeki şirket özellikleri ile COVID-19'a karşı pay senedi fiyat reaksiyonu arasındaki ilişkiyi incelemişlerdir. Yapılan analiz sonuçlarına göre 2020 öncesi güçlü finansal yapıya sahip olan şirketlerin, COVID-19'a küresel tedarik zinciri ve müşteri lokasyonları ile daha az maruz kalan firmalar arasında, pandemi kaynaklı pay senedi fiyatı düşusşlerinden daha az etkilendiğini tespit etmişlerdir. Pandemi öncesi güçlü kurumsal sosyal sorumluluk politikalarına ve güçlü kurumsal yönetim yapısına sahip olan firmaların (less entrenched) da COVID-19'a karşı daha iyi fiyat performansı gösterdiklerini ortaya koymuşlardır. Ayrıca firmaların sahiplik yapısının da COVID-19 sonrası performansta etkili olduğunu bulmuşlardır.

Ashraf (2020) 64 farklı ülkeden COVID-19 vak'a ve ölüm sayılarını kullanarak, borsaların COVID19'a olan tepkisini ölçmüştür. Yapılan analiz sonuçlarında COVID-19 vak'alarındaki büyümenin borsa getirilerini olumsuz etkilediğini bulmuştur. Ayrıca borsaların vak’a sayılarındaki büyümeye olan tepkisinin ölümlerdeki büyümeye olan tepkisinden daha temkinli olduğunu ortaya koymuştur. Buna ek olarak piyasaların ilk vak'aların tespitinde daha fazla tepki verdiklerini tespit etmiştir. Diğer bir çalışmada Ji vd. (2020), potansiyel güvenli liman olarak kabul edilen varlıklardan bazılarının COVID-19 sürecindeki piyasa koşullarında pay senedi endeksine karşı etkinliğini ölçümlemişlerdir. Yapılan analiz sonuçlarında altın ve soya fasulyesi vadeli işlem sözleşmelerinin pandemi esnasında güvenli liman varlıkları oldukları bulunmuştur. Bitcoinin, foreks para birimlerinin, ham petrol vadeli sözleşmelerinin güvenli liman olmadıkları tespit edilmiştir.

De Vito ve Gomez (2020), COVID-19'un 26 adet ülkenin likiditesi üzerindeki etkisini araştırmışlardır. En olumsuz durumda ortalama bir firmanın 2 yıl içerisinde nakdini tüketeceğini 
bulmuşlardır. Bu aşamada cari borçların sürdürülebilir seviyeyi aşacağı ve likidite sıkışmasını önlemek için yaklaşık \%53 civarında cari olmayan borç enjeksiyonuna ihtiyaç duyulacağını tespit etmişlerdir. Ayııca tüm firmaların yaklaşık \%10'unun 6 ay içerisinde likiditesini yitireceğini belirtmişlerdir. Zhang vd. (2020) araştırmalarında üç ana konu üzerinde çalışışlardır. İlk olarak menkul kıymetler borsa risklerinin COVID-19'a nasıl tepki verdiğini araştırmışlardır. İkinci olarak dünya genelinde sistematik riskin artıp artmadığına bakmışlardır. Son olarak politika müdahalelerinin etkilerini incelemişlerdir. Tüm ülke borsalarından verilerle çalışmışlardır. Yapılan analizlere göre finansal piyasa risklerinin pandemi sonrası arttığını göstermişlerdir. Her ülkedeki salgının şiddetine göre bu riskin değişiklik gösterdiğini belirtmişlerdir. Salgının belirsizliği ve yarattı̆ğ ekonomik kayıpların piyasaların yüksek volatiliteye sahip olmasına neden olduğunu ortaya koymuşlardır. Alışılagelmiş olmayan politika müdahalelerinin daha çok belirsizliğe yol açtı̆̆ını ve bunun uzun dönemde de devam edeceğini söylemişlerdir. Diğer ülkelerden pandemi konusunda ulusal politikalar yönünden ayrışmanın da söz konusu ülke için tehdit oluşturacağını tespit etmişlerdir. Alfora vd. (2020), COVID-19'un ABD finansal piyasaları üzerindeki etkisini araştırmışardır. Vak'a sayısının ikiye katlanmasının ertesi günkü ABD piyasa getirisini $\% 4$ ila $\% 11$ arası düşürdüğünü bulmuşlardır. Vak’a sayısının azalmasının ise piyasa getirisini arttırdığını tespit etmişlerdir. Sermaye yoğun olan ve fazla kaldıraçlı şirketlerin piyasa değerindeki düşüşten daha fazla etkilendiği göstermişlerdir.

Sharif vd. (2020) COVID-19'un ve petrol fiyatlarının, jeopolitik risk seviyeleri, ekonomi politikalarının belirsizliği ve borsaların volatiliteleri üzerinde etkisi olduğunu tespit etmişlerdir. Ayrıca COVID-19'un jeopolitik risk üzerindeki etkisinin ABD ekonomik belirsizliği üzerindeki etkisinden daha fazla olduğunu göstermişlerdir. Sansa (2020), 1 Mart-25 Mart 2020 arasinda COVID-19'un finansal piyasalar üzerindeki etkisini incelemiştir. Şangay borsası ve New York Dow Jones endeksi verileri ile yapılan analiz sonuçlarına göre COVID-19'un her iki piyasa üzerinde pozitif ve anlamlı etkisi olduğunu bulmuştur. Zeren ve Hizarcı (2020), COVID-19 kaynaklı ölümlerin ve vak’aların Çin, Güney Kore, İtalya, Fransa, Almanya ve İspanya finansal piyasaları ile ilişkisini incelemişlerdir. Ölümlerin tüm finansal piyasaları etkilediği fakat vak’a sayllarının duyurulmasının tüm finansal piyasaları etkilemediği sonucuna varmışlardır. İtalya, Fransa ve Almanya finansal piyasalarının vak'a duyumlarından etkilenmediğini ve bunun bu ülkelerde etkin piyasa hipotezinin aksine davranıssal finans teorilerine göre davranılmasından kaynaklandığını belirtmişlerdir.

\section{Yöntem}

Çalışmada, 15.02.2019-20.03.2020 tarihleri arasında BİST-100 endeksi ile BİST-30 endeksinde yer alan pay senetlerine ait veriler kullanılmıştır. BIST-100 endeksinin günlük kapanış değerleri ve BİST-30 kapsamındaki pay senetlerinin günlük kapanış fiyatları FINNET veri tabanından elde edilmiştir. Çalışma kapsamında incelenen şirketler ve şirket kodlarına ilişkin bilgiler Tablo 1'de gösterilmiştir.

Tablo 1. BIST-30 Endeksinde Yer Alan Șirketlerin Bilgileri

\begin{tabular}{|c|c|c|c|c|c|}
\hline Sira & Kod & Şirket Ad1 & Sira & Kod & Sirket Ad1 \\
\hline 1 & $\mathrm{AKBNK}$ & Akbank T.A.Ș. & 16 & SAHOL & Hac1 Ömer Sabanc1 Holding A.Ș. \\
\hline 2 & ARCLK & Arçelik A.Ş. & 17 & SODA & Soda Sanayii A.Ş. \\
\hline 3 & ASELS & Aselsan Elektronik Sanayi ve Ticaret A.Ș. & 18 & SISE & Türkiye Șișe ve Cam Fabrikaları A.Ș \\
\hline 4 & BIMAS & BİM Birleşik Mağazalar A.Ş. & 19 & HALKB & Türkiye Halk Bankası A.Ş. \\
\hline 5 & DOHOL & Doğan Șirketler Grubu Holding A.Ș. & 20 & TSKB & Türkiye Sınai Kalkınma Bankası A.S S \\
\hline 6 & EKGYO & Emlak Konut Gayrimenkul Yatırım Ort. A.Ş. & 21 & TAVHL & TAV Havalimanları Holding A.Ş. \\
\hline 7 & EREGL & Ereğli Demir ve Çelik Fabrikaları Ticaret A.Ş. & 22 & TKFEN & Tekfen Holding A.Ş. \\
\hline 8 & GARAN & Türkiye Garanti Bankası A.Ș. & 23 & TOASO & Tofaş Türk Otomobil Fabrikası A.Ș. \\
\hline 9 & ISCTR & Türkiye İş Bankası A.Ş. & 24 & TRKCM & Trakya Cam Sanayii A.Ș. \\
\hline 10 & KRDMD & Kardemir Karabük Demir Çelik S. ve T. A.Ș. & 25 & TCELL & Turkcell İletișim Hizmetleri A.Ș. \\
\hline 11 & KCHOL & Koç Holding A.Ş. & 26 & TUPRS & Tüpraş-Türkiye Petrol Raf. A.Ş. \\
\hline 12 & KOZAL & Koza Altın İşletmeleri A.Ş & 27 & THYAO & Türk Hava Yolları Anonim Ortaklığ \\
\hline 13 & KOZAA & Koza Anadolu Metal Madencilik İșl. A.S & 28 & TTKOM & Türk Telekomünikasyon A.S. \\
\hline 14 & PGSUS & Pegasus Hava Taşımacıllı̆̆1 A.Ş. & 29 & VAKBN & Türkiye Vakıflar Bankası T.A.O \\
\hline 15 & PETKM & Petkim Petrokimya Holding A.Ș. & 30 & YKBNK & Yap1 ve Kredi Bankası A.Ș. \\
\hline
\end{tabular}

Kaynak: Kamuyu Aydinlatma Platformu (KAP) 
Bu çalışmada olay etüdü (çalışması) (event study) yöntemi kullanılmıştır. Olay çalışması yöntemi, belirli bir olayın pay senedi fiyatlannda anormal bir getiriye neden olup olmadığının belirlenmesinde kullanılan bir yöntemdir (Kim vd., 2020, s. 35). Bu yöntem, pay senetleri hakkında söylentilerin, analist tavsiyelerinin, ilk halka arzların, bedelli veya bedelsiz sermaye artırımlarının, birleşme ve satın almaların, temettü duyurularının, denetim raporları ve derecelendirmelerin, finansal tablolara ilisskin duyuruların, makroekonomik duyurular ve politik gelişmelerin pay senedi üzerindeki etkilerinin değerlendirilmesi (Basdas ve Oran, 2014, s. 171-177) gibi oldukça geniş bir kullanım alanına sahiptir. Bu çalışsmada iki ayrı olayın pay senedi getirileri üzerindeki etkileri araştırılmıştır. Bunlardan ilki, Suriye'nin İdlip şehrinde rejim güçlerinin hava saldırısı sonucunda Türk askerlerinin şehit olması sonrasında SPK tarafindan pay piyasalarında açığa satışın yasaklanmasının pay senedi getirileri üzerindeki etkilerinin araştırılmasıdır. Diğeri ise Çin Halk Cumhuriyeti Hubei Eyaleti Wuhan şehrinde başladığı kabul edilen ve kısa sürede tüm dünyayı etkisi altına alan COVID-19 virüs salgını sonrası Borsa İstanbul Genel Müdürlüğü tarafindan uygulamaya konulan pay piyasasında devre kesici tetikleme oranı ile günlük fiyat değişim limitlerinde yapılan değişikliklerin pay senedi getirileri üzerindeki etkilerinin değerlendirilmesidir.

İdlip'te rejim güçleri tarafından Türk askerlerine yönelik hava saldırısı 27 Şubat 2020 tarihinde gerçekleştirilmiştir. Ardından 28 Şubatta SPK, BİST pay piyasalarında açığa satışı yasakladığını duyurarak aynı gün uygulamaya koymuştur. Karar sonrası 2 Mart 2020 tarihinde SPK tarafindan yapilan yeni açıklamada, yeni bir duyuru yapılıncaya kadar pay piyasalarında açığa satış yasağının devam edeceği bildirilmiştir. Dolayısıyla bu saldırının pay senedi getirileri üzerindeki etkisini değerlendirmek için 28 Şubat 2020 olay günü olarak kabul edilmiştir.

Türkiye'de ilk COVID-19 vak'asının bildirildiği tarih 11 Mart 2020'dir. Aynı gün DSÖ virüs salgını için pandemi ilan etmiştir. Bu gelişmelerin ardından 12 Mart 2020 tarihinde Borsa İstanbul Genel Müdürlüğü tarafindan, Yıldız Pazar ve Ana Pazar tüm gruplarında işlem gören paylarda uygulanan fiyat marjının \%10'a düşürülmesi, Yıldız Pazar ve Ana Pazar tüm gruplarında işlem gören paylarda uygulanan devre kesici tetikleme oranının \%5'e düşürülmesi, Yıldız Pazar ve Ana Pazarda işlem gören paylarda uygulanan devre kesici sonrası emir toplama süresinin 30 dakika olarak uygulanmasına karar verilmiştir. Tablo 2'de gösterilen bu oranlara ilişkin karar 13 Mart 2020 tarihinde uygulamaya konulmuştur. Yine 17 Mart 2020 tarihinde Borsa İstanbul Genel Müdürlüğü tarafindan yapılan yeni bir duyuruda, pay piyasasında sürekli işlem yöntemi ile işlem görmekte olan sıralarda aşağ1 ve yukarı yönlü $\% 5$ olarak uygulanmakta olan devre kesici tetikleme oranının, ikinci bir duyuruya kadar yukarı yönlü olarak kaldırıldığı, ilgili sıralarda \%5 devre kesici tetikleme oranının aşağı yönlü olarak uygulanmaya devam edileceği bildirilmiştir. Dolayısıyla açı̆̆a satış yasağı devam ederken COVID-19 salgını sonrası BİST tarafindan pay senetlerinin fiyatlarındaki sert dalgalanmaları sınırlamak için alınan tedbirlerin pay senedi getirileri üzerindeki etkilerini değerlendirmek için 13 Mart 2020 olay günü olarak kabul edilmiştir.

Tablo 2. BIST Pay Piyasası Fiyat Marjı ve Devre Kesici Uygulama Oranlar

\begin{tabular}{|c|c|c|c|c|c|c|c|c|}
\hline \multirow{3}{*}{$\begin{array}{l}\text { Fiyat Marjları ve } \\
\text { Devre Kesici Oranları }\end{array}$} & \multicolumn{4}{|c|}{ Eski Uygulama } & \multicolumn{4}{|c|}{ Yeni Uygulama } \\
\hline & \multicolumn{2}{|c|}{ Yildiz Pazar } & \multicolumn{2}{|c|}{ Ana Pazar } & \multicolumn{2}{|c|}{ Yildiz Pazar } & \multicolumn{2}{|c|}{ Ana Pazar } \\
\hline & Grup 1 & Grup 2 & Grup 1 & Grup 2 & Grup 1 & Grup 2 & Grup 1 & Grup 2 \\
\hline Fiyat Marj1 & $\% 20$ & $\% 20$ & $\% 20$ & $\% 15$ & $\% 10$ & $\% 10$ & $\% 10$ & $\% 10$ \\
\hline $\begin{array}{l}\text { Devre Kesici } \\
\text { Tetikleme Oranı }\end{array}$ & $\% 10$ & $\% 10$ & $\% 10$ & $\% 7,5$ & $\% 5$ & $\% 5$ & $\% 5$ & $\% 5$ \\
\hline Devre Kesici Sonras1 & 5 & 5 & 5 & 25 & 30 & 30 & 30 & 30 \\
\hline Emir Toplama Süresi & Dakika & Dakika & Dakika & Dakika & Dakika & Dakika & Dakika & Dakika \\
\hline
\end{tabular}

\section{Kaynak: BİST}

Olay çalışması yönteminin uygulanmasında olay tarihi, olay penceresi ve tahmin penceresinin belirlenmesi gerekmektedir (Mishra, 2005, s. 10). Olay tarihi, pay senedi getirisi üzerinde etkiye sahip olduğu düşünülen olayın gerçekleşme tarihidir (Erol ve Aytekin, 2018, s. 902). Olay penceresi, olay tarihinden önceki ve sonraki günleri kapsayan bir zaman periyodudur. Bu çalışmada, olay penceresi olarak $-/+5$ gün kullanılmıştır. Tahmin penceresi ise, olay penceresinden önceki 252 iş günü $(-6,-257)$ olarak belirlenmiştir.

Olay etüdü yöntemi kullanılarak yapılan çalışmalarda farklı metodolojiler kullanılmakla birlikte, en temel farklılık, anormal getiri tespitinde kullanılan beklenen getiri hesaplamasında ortaya çıkmaktadır (Kıllç, 2020, s. 69). Bu çalışmada, literatürde beklenen getiri hesaplamasında sıklıkla kullanılan Piyasa Modeli (Market Model) kullanılmıştır.

Olay etüdü çalışmasının uygulanmasında gerçekleştirilen aşamalar aşağıdaki gibidir: 
1.aşamada pay senetlerinin günlük kapanış fiyatlarından hareketle pay senetlerinin basit getirileri hesaplanmaktadır (Yılmaz ve Gülay, 2006, s. 24).

$\mathrm{R}_{\mathrm{it}}=\frac{\mathrm{P}_{\mathrm{it}}-\mathrm{P}_{\mathrm{it}-1}}{\mathrm{P}_{\mathrm{it}-1}}$

Yukarıdaki formülde $R_{i t}$ i. pay senedinin $t$ günündeki getirisini göstermektedir. $P_{i t}$ ise şirketin pay senedinin $t$ günündeki kapanış fiyatını, $P_{i t-1}$ yine pay senedinin $t$ gününden bir işgünü öncesinde $(t-1)$ gerçekleşen kapanış fiyatını temsil etmektedir.

2. aşamada pazar getirisi aşağıdaki formül yardımıyla hesaplanmıştır (Aygören ve Uyar, 1996, s. 37):

$\mathrm{R}_{\mathrm{mt}}=\frac{\mathrm{I}_{\mathrm{t}}-\mathrm{I}_{\mathrm{t}-1}}{\mathrm{I}_{\mathrm{t}-1}}$

Burada It BİST-100 endeksinin t günündeki kapanış değerini, $\mathrm{I}_{\mathrm{t}-1}$ ise BİST-100 endeksinin $\mathrm{t}-1$ günündeki kapanış değerini göstermektedir.

3. aşamada piyasa modeline ilişkin hesaplama yapılmaktadır (Kim vd., 2020, s. 35):

$\mathrm{R}_{\mathrm{it}}=\alpha_{\mathrm{it}}+\beta \mathrm{R}_{\mathrm{mt}}+\varepsilon_{\mathrm{it}}$

Burada $R_{i t}$ i pay senedinin t zamanındaki getirisini, $\alpha_{i t}$ sabit terimi, $\beta$ pay senedinin sistematik riskini, $\mathrm{R}_{\mathrm{mt}} \mathrm{t}$ gününde piyasa getirisini göstermektedir. Yukarıdaki denklemde yer alan $\alpha_{i t}$ ve $\beta$ parametreleri En Küçük Kareler regresyon yöntemi ile elde edilmiştir.

4. aşamada olay penceresi içerisindeki anormal getiri hesaplaması yapılmaktadır. Anormal getiri, olay penceresindeki günler için gerçekleşen getiri ile beklenen getiri arasındaki farkı ifade etmektedir (Hekimoğlu ve Tanyeri, 2011, s. 7).

$\mathrm{AR}_{\mathrm{it}}=\mathrm{R}_{\mathrm{it}}-\left(\widehat{\alpha}+\widehat{\beta} \mathrm{R}_{\mathrm{mt}}\right)$

5. aşamada hesaplanan anormal getirilerden hareketle ortalama anormal getiriler hesaplanmıştır (Liu vd., 2020, s. 6).

$\mathrm{AAR}_{\mathrm{i}, \mathrm{t}}=\frac{1}{\mathrm{~N}} \sum_{\mathrm{i}=1}^{\mathrm{N}} \mathrm{AR}_{\mathrm{it}}$

Ortalama anormal getiriler her bir t günündeki anormal getirilerin ortalamasını göstermektedir.

6. aşamada kümülatif anormal getiriler aşağıdaki formül yardımıyla hesaplanmısstır (Goodell ve Huynh, 2020, s. 4):

$\mathrm{CAR}_{\mathrm{i}\left(\mathrm{t}_{0}, \mathrm{t}_{1}\right)}=\sum_{\mathrm{t}=\mathrm{t}_{0}}^{\mathrm{t}_{1}} \mathrm{AR}_{\mathrm{it}}$

7. aşamada ortalama anormal getirilerin kümülatifi hesaplanmıştır. Bunun için aşağıdaki formül kullanılmıştır (Suresha ve Chandrashekara, 2016, s. 74):

$\operatorname{CAAR}_{\left(\mathrm{t}_{0}, \mathrm{t}_{1}\right)}=\sum_{\mathrm{t}=\mathrm{t}_{0}}^{\mathrm{t}_{1}} \mathrm{AAR}_{\mathrm{it}}$

Anormal getiriler ile kümülatif anormal getirilerin istatiksel olarak anlamlılığ $\mathrm{t}$ testi ile sınanmıştır. Bu kapsamda çalışmanın hipotezleri aşağıdaki gibi belirlenmiştir:

$\mathrm{H}_{0}=$ Çalışma kapsamında incelenen olay günü etrafindaki günlerde anormal getiri ve kümülatif anormal getiri 0'a eşittir. (ARt $=0, \mathrm{CARt}=0)$

$\mathrm{H}_{1}=$ Çalışma kapsamında incelenen olay günü etrafindaki günlerde anormal getiri ve kümülatif anormal getiri 0 'dan farklıdır. (ARt $\neq 0$, CARt $\neq 0$ )

\section{Bulgular}

Çalışma kapsamında incelenen şirketlerin açığa satış yasağı kapsamında olay penceresindeki kümülatif anormal getirileri Tablo 3’te gösterilmiştir. 
Tablo 3. Açı̆̆a Satış Yasă̆ı Uygulaması Kapsamında Şirketlerin Olay Penceresinde Kümülatif Anormal Getirileri $\left(C A R_{t}\right)$

\begin{tabular}{|c|c|c|c|c|c|c|c|c|c|c|}
\hline \multirow{2}{*}{$\begin{array}{c}\text { Olay } \\
\text { Penceresi }\end{array}$} & $A K B N K$ & $A R C L K$ & ASELS & BIMAS & DOHOL & EKGYO & EREGL & SAHOL & KRDMD & KCHOL \\
\hline & $C A R_{t}$ & $C A R_{t}$ & $C A R_{t}$ & $C A R_{t}$ & $C A R_{t}$ & $C A R_{t}$ & $C A R_{t}$ & $C A R_{t}$ & $C A R_{t}$ & $C A R_{t}$ \\
\hline-5 & $-0,0063$ & 0,0016 & 0,0045 & 0,0015 & 0,0114 & $-0,0051$ & 0,0094 & $-0,0130$ & 0,0271 & $-0,0043$ \\
\hline-4 & $-0,0006$ & $-0,0064$ & 0,0173 & 0,0054 & 0,0003 & 0,0015 & $-0,0093$ & $-0,0081$ & 0,0520 & $-0,0253$ \\
\hline-3 & $-0,0055$ & $-0,0115$ & 0,0396 & $-0,0165$ & 0,0003 & $-0,0011$ & $-0,0080$ & $-0,0191$ & 0,0525 & $-0,0309$ \\
\hline-2 & 0,0013 & $-0,0085$ & 0,0262 & 0,0067 & $-0,0171$ & $-0,0024$ & 0,0159 & $-0,0151$ & 0,0750 & $-0,0127$ \\
\hline-1 & 0,0151 & 0,0033 & 0,0396 & 0,0153 & $-0,0442$ & 0,0109 & 0,0073 & $-0,0034$ & 0,0642 & $-0,0189$ \\
\hline 0 & 0,0135 & 0,0240 & 0,0697 & 0,0396 & $-0,0750$ & 0,0013 & 0,0041 & $-0,0040$ & 0,0661 & $-0,0416$ \\
\hline 1 & 0,0110 & $-0,0048$ & 0,0816 & 0,0159 & $-0,0799$ & 0,0161 & $-0,0052$ & 0,0213 & 0,0808 & $-0,0374$ \\
\hline 2 & 0,0084 & 0,0000 & 0,1177 & 0,0148 & $-0,0602$ & 0,0172 & $-0,0047$ & 0,0064 & 0,0758 & $-0,0313$ \\
\hline 3 & 0,0488 & 0,0132 & 0,0990 & 0,0341 & $-0,0767$ & 0,0080 & $-0,0268$ & 0,0530 & 0,0513 & $-0,0376$ \\
\hline 4 & 0,0281 & -0,0087 & 0,1045 & 0,0982 & $-0,0797$ & $-0,0025$ & 0,0194 & 0,0371 & 0,0501 & $-0,0527$ \\
\hline 5 & 0,0394 & $-0,0371$ & 0,1132 & 0,1193 & $-0,1081$ & $-0,0008$ & 0,0521 & 0,0395 & 0,0524 & $-0,0623$ \\
\hline \multirow{2}{*}{$\begin{array}{c}\text { Olay } \\
\text { Penceresi }\end{array}$} & KOZAL & KOZAA & PGSUS & PETKM & SODA & $T A V H L$ & TKFEN & TOASO & TRKCM & TCELL \\
\hline & $C A \boldsymbol{R}_{t}$ & $C A R_{t}$ & $C A \boldsymbol{R}_{t}$ & $C A \boldsymbol{R}_{t}$ & $C A R_{t}$ & $C A \boldsymbol{R}_{t}$ & $C A R_{t}$ & $C A \boldsymbol{R}_{t}$ & $C A R_{t}$ & $C A \boldsymbol{R}_{t}$ \\
\hline-5 & 0,0451 & 0,1056 & 0,0029 & 0,0046 & 0,0090 & $-0,0112$ & $-0,0400$ & $-0,0010$ & 0,0102 & $-0,0167$ \\
\hline-4 & 0,0781 & 0,1294 & $-0,0181$ & 0,0027 & 0,0168 & $-0,0320$ & $-0,0404$ & $-0,0101$ & 0,0130 & $-0,0231$ \\
\hline-3 & 0,0540 & 0,1177 & $-0,0357$ & 0,0040 & 0,0124 & $-0,0494$ & $-0,0370$ & 0,0210 & 0,0416 & 0,0092 \\
\hline-2 & 0,0416 & 0,0997 & $-0,0688$ & $-0,0013$ & 0,0098 & $-0,0724$ & $-0,0356$ & 0,0339 & 0,0353 & $-0,0096$ \\
\hline-1 & 0,0350 & 0,0912 & $-0,1289$ & $-0,0087$ & $-0,0060$ & $-0,0907$ & $-0,0625$ & 0,0318 & 0,0224 & 0,0047 \\
\hline 0 & $-0,0317$ & 0,0613 & $-0,1664$ & $-0,0005$ & $-0,0235$ & $-0,1445$ & $-0,0805$ & 0,0769 & 0,0141 & 0,0217 \\
\hline 1 & $-0,0374$ & 0,0461 & $-0,1718$ & 0,0088 & -0,0198 & $-0,1532$ & $-0,0530$ & 0,0642 & 0,0207 & 0,0100 \\
\hline 2 & $-0,0424$ & 0,0755 & $-0,1760$ & 0,0027 & $-0,0246$ & $-0,1536$ & $-0,0578$ & 0,0717 & 0,0078 & 0,0143 \\
\hline 3 & $-0,0530$ & 0,0220 & $-0,2538$ & $-0,0171$ & $-0,0277$ & $-0,1837$ & $-0,0727$ & 0,0648 & 0,0058 & 0,0422 \\
\hline 4 & $-0,0558$ & 0,0091 & $-0,2978$ & $-0,0297$ & $-0,0160$ & $-0,2079$ & $-0,0658$ & 0,0446 & $-0,0142$ & 0,0517 \\
\hline 5 & $-0,0294$ & 0,0175 & $-0,3232$ & $-0,0527$ & $-0,0340$ & $-0,2209$ & $-0,0776$ & 0,0217 & $-0,0366$ & 0,0465 \\
\hline \multirow{2}{*}{$\begin{array}{c}\text { Olay } \\
\text { Penceresi }\end{array}$} & TUPRS & THYAO & ТТКОM & $G A R A N$ & $H A L K B$ & ISCTR & TSKB & SISE & $V A K B N$ & $Y K B N K$ \\
\hline & $C A R_{t}$ & CAR $_{t}$ & $C A R_{t}$ & $C A R_{t}$ & $C A R_{t}$ & $C A R_{t}$ & $C A R_{t}$ & $C A R_{t}$ & $C A R_{t}$ & $C A R_{t}$ \\
\hline-5 & $-0,0002$ & $-0,0025$ & 0,0245 & $-0,0112$ & $-0,0082$ & $-0,0184$ & 0,0037 & $-0,0052$ & $-0,0101$ & 0,0061 \\
\hline-4 & 0,0125 & $-0,0252$ & 0,0142 & $-0,0152$ & $-0,0214$ & $-0,0226$ & 0,0215 & 0,0078 & $-0,0171$ & 0,0082 \\
\hline-3 & 0,0007 & $-0,0476$ & 0,0137 & $-0,0170$ & $-0,0189$ & $-0,0287$ & 0,0164 & 0,0147 & $-0,0131$ & 0,0045 \\
\hline-2 & $-0,0062$ & $-0,0742$ & 0,0061 & $-0,0313$ & $-0,0167$ & $-0,0221$ & 0,0155 & 0,0166 & 0,0028 & 0,0031 \\
\hline-1 & $-0,0313$ & $-0,1031$ & 0,0105 & $-0,0071$ & $-0,0226$ & 0,0002 & $-0,0118$ & 0,0323 & 0,0152 & 0,0033 \\
\hline 0 & $-0,0168$ & $-0,0842$ & $-0,0035$ & $-0,0111$ & $-0,0131$ & $-0,0113$ & $-0,0373$ & 0,0264 & 0,0174 & $-0,0128$ \\
\hline 1 & $-0,0250$ & $-0,0956$ & $-0,0160$ & $-0,0238$ & $-0,0118$ & $-0,0104$ & $-0,0247$ & 0,0400 & 0,0274 & 0,0149 \\
\hline 2 & $-0,0416$ & $-0,1065$ & 0,0167 & $-0,0173$ & 0,0092 & $-0,0024$ & $-0,0121$ & 0,0169 & 0,0494 & 0,0405 \\
\hline 3 & $-0,0545$ & $-0,1398$ & $-0,0194$ & 0,0052 & $-0,0191$ & 0,0011 & $-0,0344$ & 0,0160 & 0,0416 & 0,0446 \\
\hline 4 & $-0,0708$ & $-0,1549$ & $-0,0014$ & $-0,0157$ & $-0,0304$ & $-0,0130$ & $-0,0284$ & 0,0039 & 0,0196 & 0,0209 \\
\hline 5 & $-0,1028$ & $-0,1778$ & $-0,0124$ & $-0,0106$ & $-0,0359$ & $-0,0075$ & $-0,0505$ & $-0,0012$ & 0,0096 & 0,0054 \\
\hline
\end{tabular}

BİST-30 endeksi şirketlerinin, açı̆̆a satış yasağ1 uygulaması kapsamında kümülatif anormal getirilerinin istatistiksel olarak anlamlılığına ilişkin p (sig.) değerleri Tablo 4’te gösterilmiştir.

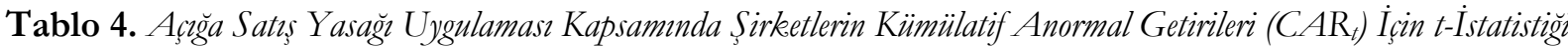

\begin{tabular}{|c|c|c|c|c|c|}
\hline Şirket & t-istatistiği & $\begin{array}{c}p \text { değeri } \\
\text { (sig.) }\end{array}$ & Şirket & t-istatistiği & $\begin{array}{c}\text { p değeri } \\
\text { (sig.) }\end{array}$ \\
\hline AKBNK & $2,556^{* *}$ & 0,029 & TAVHL & $-5,491 *$ & 0,000 \\
\hline ARCLK & $-0,681$ & 0,511 & TKFEN & $-11,285^{*}$ & 0,000 \\
\hline ASELS & $5,239 *$ & 0,000 & TOASO & $4,328^{*}$ & 0,001 \\
\hline BIMAS & $2,410 * *$ & 0,037 & TRKCM & 1,670 & 0,126 \\
\hline DOHOL & $-3,927^{*}$ & 0,003 & TCELL & 1,810 & 0,100 \\
\hline EKGYO & 1,658 & 0,128 & TUPRS & $-2,913^{* *}$ & 0,015 \\
\hline EREGL & 0,802 & 0,441 & THYAO & $-5,685$ & 0,000 \\
\hline SAHOL & 1,138 & 0,282 & TTKOM & 0,683 & 0,510 \\
\hline KRDMD & $12,656^{*}$ & 0,000 & GARAN & $-5,035^{*}$ & 0,001 \\
\hline KCHOL & $-6,337^{*}$ & 0,000 & HALKB & $-4,805^{*}$ & 0,001 \\
\hline KOZAL & 0,024 & 0,981 & ISCTR & $-4,132^{*}$ & 0,002 \\
\hline KOZAA & $5,534^{*}$ & 0,000 & TSKB & $-1,753$ & 0,110 \\
\hline PGSUS & $-4,418^{*}$ & 0,001 & SISE & $3,671^{*}$ & 0,004 \\
\hline PETKM & $-1,412$ & 0,188 & VAKBN & $1,994 * * *$ & 0,074 \\
\hline SODA & $-1,695$ & 0,121 & YKBNK & $2,465^{* *}$ & 0,033 \\
\hline
\end{tabular}

Not: $*, * *, * * *$ sirasiyla $\% 1, \% 5$ ve $\% 10$ anlamlllık düzeyini göstermektedir. 
Tabloda yer alan sonuçlara bakıldığında ASELS, DOHOL, KRDMD, KCHOL, KOZAA, PGSUS, TAVHL, TKFEN, TOASO, GARAN, HALKB, ISCTR ve SISE hisselerinin \%1 anlamlllik seviyesinde, AKBNK, BIMAS, TUPRS, YKBNK hisselerinin \%5 anlamlllk seviyesinde ve son olarak VAKBN hissesinin ise \%10 anlamlılık seviyesinde istatistiksel olarak anlamlı kümülatif anormal getiri sunduğu görülmektedir. Geriye kalan 12 hisse senedinin kümülatif anormal getirileri istatistiksel olarak anlamlı bulunmamıstır. Dolayısıyla şirket bazında incelenen kümülatif anormal getiri açısından $\mathrm{H}_{0}$ hipotezinin reddedilerek $\mathrm{H}_{1}$ hipotezinin kabul edildiği söylenebilir.

Tablo 5. Aç̧̆ga Satış Yasağı Uygulaması Kapsamunda Olay Penceresinde Ortalama Anormal Getiriler $\left(A A_{t}\right)$ ve Kümülatif Ortalama Anormal Getiriler $\left(C A A R_{t}\right)$

\begin{tabular}{|c|c|c|c|c|c|c|}
\hline \multirow{2}{*}{$\begin{array}{c}\text { Olay } \\
\text { Penceresi }\end{array}$} & \multicolumn{2}{|c|}{$A R_{t}$} & \multicolumn{2}{|c|}{$C A R_{t}$} & \multirow[b]{2}{*}{$\boldsymbol{A A R} \boldsymbol{R}_{t}$} & \multirow[b]{2}{*}{$C A A R_{t}$} \\
\hline & t-istatistiği & $\begin{array}{c}p \text { değeri } \\
\text { (sig.) }\end{array}$ & t-istatistiği & $\begin{array}{c}p \text { değeri } \\
\text { (sig.) }\end{array}$ & & \\
\hline-5 & 0,845 & 0,405 & 0,845 & 0,405 & 0,0038 & 0,0038 \\
\hline-4 & $-0,102$ & 0,920 & 0,568 & 0,575 & $-0,0003$ & 0,0035 \\
\hline-3 & $-0,544$ & 0,591 & 0,329 & 0,745 & $-0,0014$ & 0,0021 \\
\hline-2 & $-0,826$ & 0,416 & $-0,022$ & 0,982 & $-0,0022$ & $-0,0002$ \\
\hline-1 & $-1,270$ & 0,214 & $-0,542$ & 0,592 & $-0,0044$ & $-0,0046$ \\
\hline 0 & $-1,392$ & 0,175 & $-1,038$ & 0,308 & $-0,0062$ & $-0,0107$ \\
\hline 1 & 0,138 & 0,891 & $-0,979$ & 0,335 & 0,0004 & $-0,0104$ \\
\hline 2 & 1,521 & 0,139 & $-0,542$ & 0,592 & 0,0042 & $-0,0062$ \\
\hline 3 & $-1,974 * * *$ & 0,058 & $-1,137$ & 0,265 & $-0,0093$ & $-0,0155$ \\
\hline 4 & $-1,645$ & 0,111 & $-1,456$ & 0,156 & $-0,0064$ & $-0,0219$ \\
\hline 5 & $-2,234 * *$ & 0,033 & $-1,727 * * *$ & 0,095 & $-0,0069$ & $-0,0288$ \\
\hline
\end{tabular}

Not: *,**, *** sirasıyla $\% 1, \% 5$ ve $\% 10$ anlamlllık düzeyini göstermektedir.

Ortalama anormal getiriler ve kümülatif ortalama anormal getirilerin gösterildiği Tablo 5'de yer alan bilgiler incelendiğinde olay tarihinden 3 gün $(+3)$ ve 5 gün $(+5)$ sonrasında istatistiksel olarak anlamlı anormal getiri elde edilebildiği görülmektedir. Olay tarihinden 3 ve 5 gün sonrasında sırasıyla $\% 10$ ve $\% 5$ anlamlılık düzeylerinde negatif anormal getiri elde edilebildiği anlaşılmaktadır. Aynı günlerde ortalama anormal getiriler ve kümülatif ortalama anormal getiriler de negatif olarak gözlenmiştir. Olay tarihinden önceki ve sonraki diğer günlerde ise istatistiki olarak anlamlı anormal getiri elde edilememiştir.

Kümülatif anormal getirilere bakıldığında ise sadece olay tarihinden 5 gün $(+5)$ sonrasında $\% 10$ anlamlıllk düzeyinde istatistiksel olarak anlamlı negatif kümülatif anormal getiri elde edilebildiği anlaşılmaktadır. Olay tarihinden önceki ve sonraki diğer günlerde ise istatistiki olarak anlamlı kümülatif anormal getiri elde edilememiştir. Dolayısıyla olay penceresinde elde edilen anormal getiriler ve kümülatif anormal getiriler açısından $\mathrm{H}_{0}$ hipotezinin reddedilerek $\mathrm{H}_{1}$ hipotezi kabul edilmiştir.

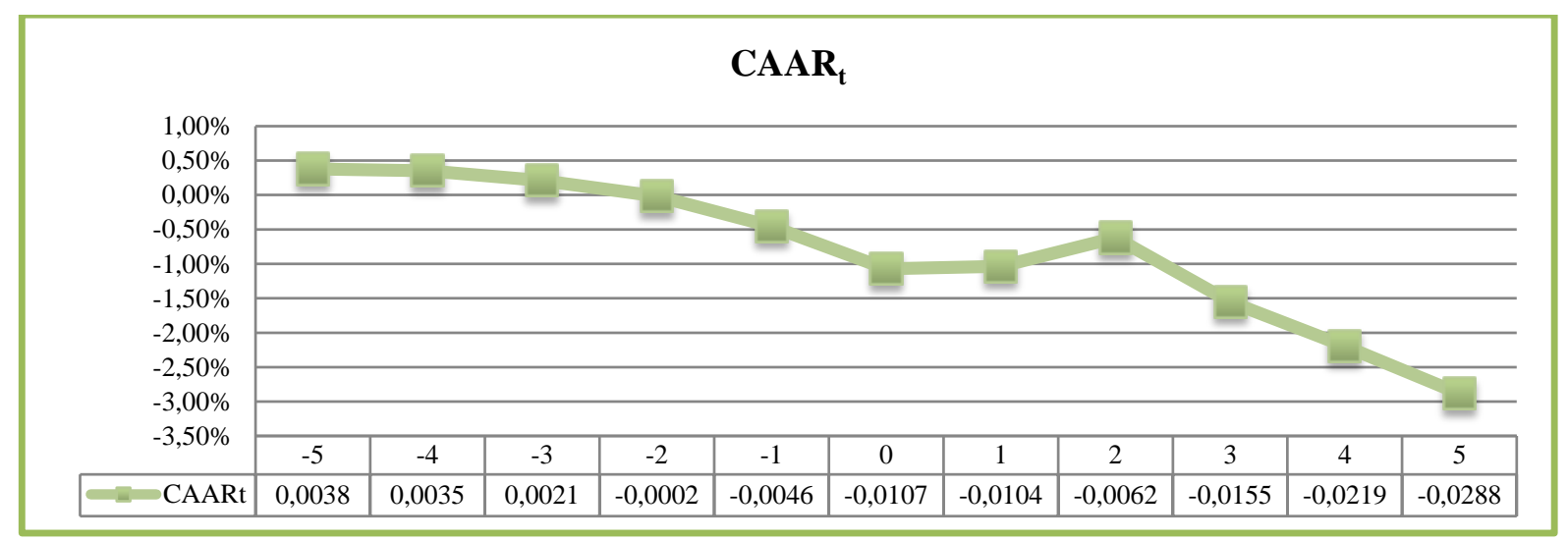

Grafik 1. Açğa Satıs Yasağ Uygulaması Kapsamında Kümülatif Ortalama Anormal Getirilerin Olay Gününe Duyarllh $\breve{g r}\left(C A A R_{t}\right)$

Açığa satış yasağ1 uygulaması kapsamında kümülatif ortalama anormal getirilerin olay gününe duyarll11kları Grafik 1'de gösterilmiştir. Kümülatif ortalama anormal getiriler, olay gününden 5 gün öncesinde (-5) pozitif ve en yüksek değere ulaşmış olmasına rağmen olay gününden önceki ikinci gün (-2) negatif değere dönmüsstür. Bu tarihten itibaren olaydan sonraki beşinci güne $(+5)$ kadar negatif seyrini 
devam ettirmiştir. Dolayısıyla olay gününde, bir önceki güne göre artan negatif kümülatif ortalama anormal getiriler olaydan bir gün sonra $(+1)$ yatay seyretmiş, olaydan iki gün sonra $(+2)$ azalmış fakat olaydan sonraki üçüncü gün $(+3)$ negatif olarak artmaya başlamıştır. Bu yönüyle bakıldığında olayın kümülatif ortalama anormal getirileri olumsuz etkilediği düşünülmektedir.

Çalışma kapsamında incelenen şirketlerin, fiyat marjı ve devre kesici uygulamaları için yapılan düzenlemeler kapsamında olay penceresindeki kümülatif anormal getirileri Tablo 6'da gösterilmiştir.

Tablo 6. Fiyat Marji ve Devre Kesici Düzenlemesi Kapsammda Şirketlerin Olay Penceresinde Kümülatif Anormal Getirileri $\left(C A R_{t}\right)$

\begin{tabular}{|c|c|c|c|c|c|c|c|c|c|c|}
\hline \multirow{2}{*}{$\begin{array}{c}\text { Olay } \\
\text { Penceresi }\end{array}$} & $A K B N K$ & $A R C L K$ & ASELS & BIMAS & DOHOL & $E K G Y O$ & EREGL & SAHOL & KRDMD & KCHOL \\
\hline & $C A R_{t}$ & $C A R_{t}$ & $C A R_{t}$ & $C A R_{t}$ & $C A R_{t}$ & $C A R_{t}$ & $C A R_{t}$ & $C A R_{t}$ & $C A R_{t}$ & $C A R_{t}$ \\
\hline-5 & 0,0449 & $-0,0371$ & 0,0022 & 0,0269 & $-0,0646$ & 0,0019 & 0,0382 & 0,0491 & $-0,0225$ & 0,0290 \\
\hline-4 & 0,1107 & $-0,0562$ & $-0,0356$ & 0,0559 & $-0,1330$ & $-0,0212$ & 0,1112 & 0,1249 & $-0,0901$ & 0,0556 \\
\hline-3 & 0,1676 & $-0,0958$ & $-0,0631$ & 0,1646 & $-0,2157$ & $-0,0742$ & 0,1616 & 0,1985 & $-0,1880$ & 0,0155 \\
\hline-2 & 0,2571 & $-0,1578$ & $-0,0753$ & 0,2511 & $-0,3260$ & $-0,1182$ & 0,2361 & 0,3204 & $-0,2788$ & $-0,0013$ \\
\hline-1 & 0,3455 & $-0,2315$ & $-0,0677$ & 0,2921 & $-0,4395$ & $-0,1421$ & 0,2790 & 0,4367 & $-0,3662$ & 0,0312 \\
\hline 0 & 0,4796 & $-0,3207$ & $-0,0662$ & 0,3035 & $-0,5941$ & $-0,1336$ & 0,3185 & 0,5558 & $-0,4409$ & 0,0511 \\
\hline 1 & 0,6525 & $-0,3830$ & $-0,0918$ & 0,2900 & $-0,7647$ & $-0,1284$ & 0,3590 & 0,6908 & $-0,4899$ & 0,0383 \\
\hline 2 & 0,8081 & $-0,4693$ & $-0,1129$ & 0,3620 & $-0,9039$ & $-0,1164$ & 0,4270 & 0,7738 & $-0,5326$ & 0,0307 \\
\hline 3 & 0,9394 & $-0,5944$ & $-0,1590$ & 0,4963 & $-1,0342$ & $-0,0902$ & 0,5223 & 0,8949 & $-0,5544$ & 0,0530 \\
\hline 4 & 1,0320 & $-0,7119$ & $-0,1999$ & 0,5807 & $-1,0725$ & $-0,0717$ & 0,6321 & 0,9978 & $-0,5855$ & 0,0238 \\
\hline 5 & 1,0320 & $-0,7119$ & $-0,1999$ & 0,5807 & $-1,0725$ & $-0,0717$ & 0,6321 & 0,9978 & $-0,5855$ & 0,0238 \\
\hline \multirow{2}{*}{$\begin{array}{c}\text { Olay } \\
\text { Penceresi }\end{array}$} & $K O Z A L$ & $K O Z A A$ & PGSUS & PETKM & SODA & $T A V H L$ & TKFEN & TOASO & $T R K C M$ & TCELL \\
\hline & $C A R_{t}$ & $C A R_{t}$ & $C A R_{t}$ & $C A R_{t}$ & $C A R_{t}$ & $C A R_{t}$ & $C A R_{t}$ & $C A R_{t}$ & $C A R_{t}$ & $C A R_{t}$ \\
\hline-5 & 0,0275 & 0,0097 & $-0,0230$ & $-0,0228$ & $-0,0168$ & $-0,0111$ & $-0,0107$ & $-0,0233$ & $-0,0220$ & $-0,0063$ \\
\hline-4 & $-0,0155$ & $-0,0516$ & $-0,0388$ & $-0,0224$ & $-0,0594$ & $-0,0195$ & $-0,0388$ & $-0,0564$ & $-0,0305$ & $-0,0142$ \\
\hline-3 & $-0,0638$ & $-0,1198$ & $-0,0944$ & $-0,0100$ & $-0,0754$ & $-0,0249$ & $-0,0511$ & $-0,0389$ & $-0,0468$ & $-0,0262$ \\
\hline-2 & $-0,0786$ & $-0,1161$ & $-0,1357$ & $-0,0263$ & $-0,1178$ & $-0,0282$ & $-0,1009$ & $-0,0493$ & $-0,0353$ & 0,0035 \\
\hline-1 & $-0,1199$ & $-0,1314$ & $-0,1860$ & $-0,0424$ & $-0,1453$ & $-0,0426$ & $-0,0913$ & $-0,0471$ & $-0,0538$ & 0,0123 \\
\hline 0 & $-0,1076$ & $-0,0772$ & $-0,1073$ & $-0,0199$ & $-0,0925$ & $-0,0291$ & $-0,0350$ & $-0,1058$ & $-0,0437$ & $-0,0296$ \\
\hline 1 & $-0,1656$ & $-0,1155$ & $-0,1372$ & $-0,0166$ & $-0,1545$ & $-0,0295$ & $-0,0093$ & $-0,1149$ & $-0,0673$ & $-0,0181$ \\
\hline 2 & $-0,1995$ & $-0,1537$ & $-0,2278$ & $-0,0390$ & $-0,1455$ & $-0,0104$ & 0,0060 & $-0,1825$ & $-0,0947$ & 0,0334 \\
\hline 3 & $-0,2192$ & $-0,1780$ & $-0,3012$ & $-0,0369$ & $-0,1338$ & $-0,0299$ & 0,0127 & $-0,2197$ & $-0,0523$ & 0,0277 \\
\hline 4 & $-0,2076$ & $-0,1678$ & $-0,3995$ & 0,0106 & $-0,1000$ & $-0,0841$ & 0,0015 & $-0,2315$ & $-0,0115$ & 0,0092 \\
\hline 5 & $-0,2197$ & $-0,1642$ & $-0,4058$ & 0,0293 & $-0,0980$ & $-0,0657$ & 0,0051 & $-0,2240$ & $-0,0254$ & 0,0711 \\
\hline \multirow{2}{*}{$\begin{array}{c}\text { Olay } \\
\text { Penceresi }\end{array}$} & TUPRS & $T H Y A O$ & TTKOM & $G A R A N$ & $H A L K B$ & ISCTR & $T S K B$ & SISE & $V A K B N$ & $Y K B N K$ \\
\hline & $C A R_{t}$ & $C A R_{t}$ & $C A R_{t}$ & $C A R_{t}$ & $C A R_{t}$ & $C A R_{t}$ & $C A R_{t}$ & $C A R_{t}$ & $C A R_{t}$ & $C A R_{t}$ \\
\hline-5 & $-0,0320$ & $-0,0223$ & $-0,0101$ & 0,0046 & $-0,0049$ & 0,0053 & $-0,0208$ & $-0,0062$ & $-0,0099$ & $-0,0148$ \\
\hline-4 & $-0,0014$ & $-0,0183$ & $-0,0434$ & 0,0068 & 0,0032 & 0,0261 & $-0,0293$ & $-0,0289$ & 0,0086 & $-0,0023$ \\
\hline-3 & 0,0001 & $-0,0263$ & $-0,0223$ & 0,0624 & 0,0196 & 0,0457 & $-0,0508$ & $-0,0320$ & 0,0330 & 0,0144 \\
\hline-2 & $-0,0279$ & $-0,0603$ & $-0,0312$ & 0,0882 & 0,0093 & 0,0488 & $-0,0308$ & $-0,0553$ & 0,0422 & 0,0327 \\
\hline-1 & $-0,0366$ & $-0,0837$ & $-0,0432$ & 0,1143 & 0,0295 & 0,0746 & $-0,0469$ & $-0,0749$ & 0,0746 & 0,0508 \\
\hline 0 & $-0,0385$ & $-0,0319$ & $-0,0549$ & 0,1119 & 0,0461 & 0,1004 & $-0,0394$ & $-0,0470$ & 0,0875 & 0,0611 \\
\hline 1 & $-0,0558$ & $-0,0268$ & $-0,0235$ & 0,1475 & 0,0855 & 0,1210 & $-0,0219$ & $-0,0410$ & 0,1234 & 0,0819 \\
\hline 2 & $-0,1157$ & $-0,0400$ & $-0,0040$ & 0,1915 & 0,1435 & 0,1739 & 0,0484 & $-0,0332$ & 0,1884 & 0,1074 \\
\hline 3 & $-0,1567$ & $-0,0313$ & $-0,0136$ & 0,1665 & 0,1413 & 0,1558 & 0,0416 & $-0,0027$ & 0,1954 & 0,0903 \\
\hline 4 & $-0,1806$ & $-0,0195$ & $-0,0165$ & 0,1208 & 0,1363 & 0,1379 & 0,0456 & 0,0212 & 0,2023 & 0,0551 \\
\hline 5 & $-0,1630$ & $-0,0226$ & 0,0362 & 0,0935 & 0,1380 & 0,1408 & 0,0585 & 0,0260 & 0,1973 & 0,0350 \\
\hline
\end{tabular}

BİST-30 endeksi şirketlerinin, açı̆̆a satış yasağı uygulaması kapsamında kümülatif anormal getirilerinin istatistiksel olarak anlamlılı̆̆ına ilişkin p (sig.) değerleri Tablo 7’de gösterilmiştir. 
Tablo 7. Fiyat Marjı ve Devre Kesici Düzenlemesi Kapsammda Şirketlerin Kümülatif Anormal Getirileri $\left(C A R_{t}\right) \dot{I}_{c} i n$ t-İstatistiği

\begin{tabular}{|c|c|c|c|c|c|}
\hline Şirket & t-istatistiği & p değeri (sig.) & Şirket & t-istatistiği & p değeri (sig.) \\
\hline AKBNK & $6,336^{*}$ & 0,000 & TAVHL & $-5,021^{*}$ & 0,001 \\
\hline ARCLK & $-6,386^{*}$ & 0,000 & TKFEN & $-2,391 * *$ & 0,038 \\
\hline ASELS & $-2,894 * *$ & 0,016 & TOASO & $-4,745^{*}$ & 0,001 \\
\hline BIMAS & $3,978^{*}$ & 0,003 & TRKCM & $-6,250^{*}$ & 0,000 \\
\hline DOHOL & $-7,002 *$ & 0,000 & TCELL & 0,633 & 0,541 \\
\hline EKGYO & $-0,812$ & 0,436 & TUPRS & $-3,613 *$ & 0,005 \\
\hline EREGL & $7,855^{*}$ & 0,000 & THYAO & $\begin{array}{l}-5,749 * \\
\end{array}$ & 0,000 \\
\hline SAHOL & $7,610^{*}$ & 0,000 & TTKOM & $-2,789 * *$ & 0,019 \\
\hline KRDMD & $-5,335^{*}$ & 0,000 & GARAN & $5,630^{*}$ & 0,000 \\
\hline $\mathrm{KCHOL}$ & 0,181 & 0,860 & HALKB & $3,645^{*}$ & 0,004 \\
\hline KOZAL & $-4,822^{*}$ & 0,001 & ISCTR & $5,465^{*}$ & 0,000 \\
\hline KOZAA & $-6,752^{*}$ & 0,000 & TSKB & $-0,321$ & 0,755 \\
\hline PGSUS & $-4,667 *$ & 0,001 & SISE & $-2,630 * *$ & 0,025 \\
\hline PETKM & $-2,751 * *$ & 0,020 & VAKBN & $4,232^{*}$ & 0,002 \\
\hline SODA & $-8,174^{*}$ & 0,000 & YKBNK & $4,026^{*}$ & 0,002 \\
\hline
\end{tabular}

Not: *,**, *** sırasıyla $\% 1, \% 5$ ve $\% 10$ anlamlllık düzeyini göstermektedir.

Tabloda yer alan sonuçlara bakıldığında AKBNK, ARCLK, BIMAS, DOHOL, EREGL, SAHOL, KRDMD, KOZAL, KOZAA, PGSUS, SODA, TAVHL, TOASO, TRKCM, TUPRS, THYAO, GARAN, HALKB, ISCTR, VAKBN ve YKBNK hisselerinin $\% 1$ anlamllik seviyesinde, ASELS, PETKM, TKFEN, TTKOM, SISE hisselerinin $\% 5$ anlamlllk seviyesinde istatistiksel olarak anlamlı kümülatif anormal getiri sunduğu görülmektedir. Geriye kalan 4 hisse senedinin kümülatif anormal getirileri istatistiksel olarak anlamlı bulunmamıştır. Dolayısıyla şirket bazında incelenen kümülatif anormal getiri açısından $\mathrm{H}_{0}$ hipotezinin reddedilerek $\mathrm{H}_{1}$ hipotezinin kabul edildiği söylenebilir.

Tablo 8. Fiyat Marji ve Devre Kesici Düzenlemesi Kapsaminda Olay Penceresinde Ortalama Anormal Getiriler $\left(A A R_{t}\right)$ ve Kümülatif Ortalama Anormal Getiriler $\left(C A A R_{t}\right)$

\begin{tabular}{|c|c|c|c|c|c|c|}
\hline \multirow{2}{*}{$\begin{array}{c}\text { Olay } \\
\text { Penceresi }\end{array}$} & \multicolumn{2}{|c|}{$\boldsymbol{A} \boldsymbol{R}_{t}$} & \multicolumn{2}{|c|}{$C A \boldsymbol{R}_{t}$} & \multirow{2}{*}{$\boldsymbol{A A} \boldsymbol{R}_{t}$} & \multirow{2}{*}{$C A A R_{t}$} \\
\hline & t-istatistiği & p değeri (sig.) & t-istatistiği & p değeri (sig.) & & \\
\hline-5 & $-2,151 * *$ & 0,040 & $-2,151 * *$ & 0,040 & $-0,0065$ & $-0,0065$ \\
\hline-4 & $-1,137$ & 0,265 & $-2,081 * *$ & 0,046 & $-0,0054$ & $-0,0119$ \\
\hline-3 & $-0,608$ & 0,548 & $-1,628$ & 0,114 & $-0,0032$ & $-0,0151$ \\
\hline-2 & $-1,720 * * *$ & 0,096 & $-2,056 * *$ & 0,049 & $-0,0089$ & $-0,0240$ \\
\hline-1 & $-0,240$ & 0,812 & $-1,680$ & 0,104 & $-0,0011$ & $-0,0251$ \\
\hline 0 & $1,910^{* * *}$ & 0,066 & $-1,086$ & 0,286 & 0,0110 & $-0,0141$ \\
\hline 1 & $-0,003$ & 0,997 & $-0,847$ & 0,404 & 0,0000 & $-0,0141$ \\
\hline 2 & 0,401 & 0,692 & $-0,508$ & 0,615 & 0,0030 & $-0,0111$ \\
\hline 3 & $-0,703$ & 0,488 & $-0,658$ & 0,515 & $-0,0039$ & $-0,0150$ \\
\hline 4 & $-0,111$ & 0,913 & $-0,641$ & 0,527 & $-0,0007$ & $-0,0157$ \\
\hline 5 & 0,402 & 0,691 & $-0,575$ & 0,570 & 0,0022 & $-0,0135$ \\
\hline
\end{tabular}

Not: *, **, *** sırasıly $\% 1, \% 5$ ve $\% 10$ anlamlllık düzeyini göstermektedir.

Ortalama anormal getiriler ve kümülatif ortalama anormal getirilerin gösterildiği Tablo 8'de yer alan bilgiler incelendiğinde olay tarihi ile olay tarihinden 2 gün (-2) ve 5 gün (-5) öncesinde istatistiksel olarak anlamlı anormal getiri elde edilebildiği görülmektedir. Olay tarihinde $\% 10$ anlamlılık düzeyinde pozitif anormal getiri elde edilebilmiştir. Olay tarihinden 2 ve 5 gün öncesinde $(-2,-5)$ ise sırasıyla $\% 10$ ve $\% 5$ anlamlılık düzeylerinde negatif anormal getiri elde edilebildiği anlaşılmaktadır. Olay tarihinde, anormal getiriler ve ortalama anormal getirilerin aksine kümülatif ortalama anormal getiriler negatifken olay tarihinden 2 ve 5 gün öncesinde $(-2,-5)$ anormal getiriler gibi ortalama anormal getiriler ve kümülatif ortalama anormal getiriler de negatiftir. Olay tarihinden önceki ve sonraki diğer günlerde ise istatistiki olarak anlamlı ortalama anormal getiri elde edilememiştir.

Kümülatif anormal getirilere bakıldığında olay tarihinden 2 gün (-2), 4 gün (-4) ve 5 gün (-5) öncesinde $\% 5$ anlamll11k düzeyinde istatistiksel olarak anlamlı negatif kümülatif anormal getiri elde edilebildiği anlaşılmaktadır. Olay tarihinden önceki ve sonraki diğer günlerde ise istatistiki olarak anlamlı 
kümülatif anormal getiri elde edilememiştir. Dolayısıyla olay penceresinde elde edilen anormal getiriler ve kümülatif anormal getiriler açısından $\mathrm{H}_{0}$ hipotezinin reddedilerek $\mathrm{H}_{1}$ hipotezi kabul edilmiştir.

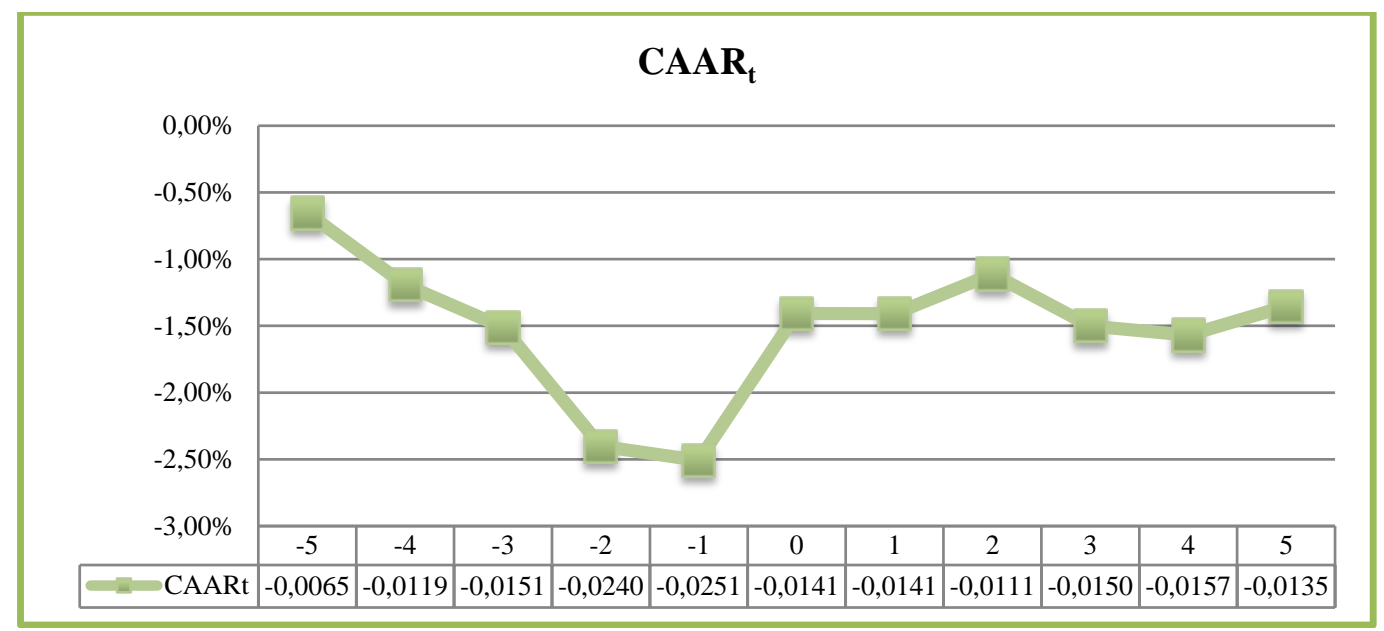

Grafik 2. Fiyat Marjı ve Devre Kesici Düzenlemesi Kapsamında Kümülatif Ortalama Anormal Getirilerin Olay Gününe Duyarllh̆̆gr $\left(C A A R_{t}\right)$

Fiyat marj1 ve devre kesici düzenlemesi kapsamında kümülatif ortalama anormal getirilerin olay gününe duyarlllıkları Grafik 2'de gösterilmiştir. Kümülatif ortalama anormal getiriler, olay penceresinin tamamında negatif olarak gerçekleşmiştir. Olay gününden 5 gün öncesinde (-5) negatif en düşük değerine ulaşmış olmasına rağmen olay gününden sonraki günler yataya yakın seyir izlemiştir. Dolayısıyla olay günü, bir önceki güne göre negatif kümülatif ortalama anormal getiri azalırken diğer günlerde alınan tedbirlerin etkisiyle negatif getirinin azaldığı görülmektedir.

\section{Tartışma, Sonuç ve Öneriler}

Bu çalışmada ilk olarak 28 Şubat 2020 tarihinde BİST tarafindan pay piyasalarında uygulanmasına karar verilen açığa satış yasağının BISST-30 şirketleri paylarının getirileri üzerindeki etkileri incelenmiştir. 28 Şubat 2020 tarihinde BİST pay piyasasında uygulamaya konulan açığa satış yasağı için $-/+5$ günlük olay penceresi oluşturulduğunda olay tarihinden 3 gün (+3) ve 5 gün (+5) sonrasında istatistiksel olarak anlamlı negatif anormal getiri elde edilebildiği görülmüsstür. Aynı günlerde ortalama anormal getiriler ve kümülatif ortalama anormal getiriler de negatif olarak gözlenmiştir. Kümülatif anormal getirilere bakıldığında ise sadece olay tarihinden 5 gün $(+5)$ sonrasında istatistiksel olarak anlamlı negatif kümülatif anormal getiri elde edilebildiği anlaşılmaktadır. Dolayısıyla açığa satış yasağı uygulaması endeksin ve pay senetlerinin değer kaybetmesini önleyememiştir. Kaldı ki açığa satışın yasaklanmasının volatiliteye ve fiyat oluşumuna olumsuz etkileri olabilmektedir. Çankaya vd. (2012) ve Sobac1 vd. (2014) BİST üzerinde yaptıkları çalışmalarda açığa satış kısıtlarının volatiliteyi azalttığını ortaya koymuşlardır. Fakat Beber ve Pagano (2013), Miller (1977), Morck vd. (2000), Bris vd. (2007) çalışmalarında açığa satış yasaklarının likiditeyi olumsuz etkilediğini, arbitrajcıların piyasadan çekilmesiyle beraber pay senetlerinin fazla değerlendiğini ve dolayısıyla piyasada fiyat etkinliğinin bozulduğunu belirtmişlerdir. Bu dönemde BİST Vadeli Isşlem ve Opsiyon Piyasasında vadeli kontratlara konu olan pay fiyatlarının spot fiyatlanından düşük seyretmesi de benzer gerekçelere dayanmaktadır. BİST pay piyasasında bu dönemde yaşanan negatif getiriler, Ofek ve Richardson (2003)'in ABD'de 2000 yılında yaşanan DotCom krizi sırasında uygulanan açığa satış yasağının pay senedi getirilerini azalttığı bulgularıyla örtüşmektedir.

Türkiye'de ilk COVID-19 vak'asının raporlanması ve DSÖ'nün virüsün yayllımını pandemi olarak ilan etmesiyle beraber pay piyasalarındaki volatiliteyi kontrol edebilmek için daha önce SPK tarafindan devreye alınan açığa satış yasağı uygulamasına ek olarak bir takım tedbirlerin alınması gereği ortaya çıkmıştır. Bu kapsamda 12 Mart 2020 tarihinde Borsa İstanbul Genel Müdürlüğü tarafindan, Yıldız Pazar ve Ana Pazar tüm gruplarında işlem gören paylarda uygulanan fiyat marjının $\% 10$ a, devre kesici tetikleme oranının $\% 5$ e düşürülmesine ve devre kesici sonrası emir toplama süresinin 30 dakika olarak uygulanmasina karar verilmiştir. Bu yeni oranlar 13 Mart tarihi itibariyle uygulamaya konulmuştur. $\mathrm{Bu}$ nedenle bu çalışmada ikinci olay tarihi 13 Mart kabul edilerek oluşturulan $-/+5$ günlük olay penceresinde yapılan analiz sonucunda olay tarihinde pozitif, olay tarihinden önceki 2. gün (-2) ve 5. gün (-5) ise istatistiksel olarak anlamlı negatif anormal getiri elde edilebildiği görülmüştür. Kümülatif anormal getirilere bakıldığında olay tarihinden önceki 2. gün (-2), 4. gün (-4) ve 5. gün (-5) istatistiksel olarak anlamlı negatif 
kümülatif anormal getiri elde edilebildiği anlaşılmaktadır. Dolayısıyla fiyat marjı ve devre kesici tetikleme oranı düzenlemeleri sonrasında pozitif anormal getiri elde edilememiştir. Fakat istatistiksel olarak anlamlı olmasa da negatif getirilerdeki artış hızı düşerek sıfıra yaklaşma trendine girmiştir. Bu trend, uygulamanın piyasada volatilite ve fiyat oluşumu etkinliği açısından faydalı olduğunu göstermektedir. COVID-19 salgının ilk kez duyurulduğu 2019 yllı Aralık ayı ile sermaye piyasalarında oluşan tedirginlik pandeminin Avrupa'ya ve gelişmiş ülkelere yayılmasıyla daha da artmıştır. Bu noktada borsalardan para çıkışının olması beklenen bir durumdur. Alfora vd. (2020), Ashraf (2020) ve Al-Awadhi vd. (2020) çalışmalarında vak'a ve ölüm sayısındaki artışın borsalarda getiriyi azalttığını belirterek bu duruma dikkat çekmişlerdir. Dünya ekonomisinde oluşacak daralmanın tahmin edilmesinin bile güçleştiği büyük belirsizlikler olan bu dönemde, SPK ve BIST tarafindan volatiliteyi azaltmak için atılan adımların birer zorunluluk olduğu görülmektedir. Kaldı ki Baker vd. (2020) COVID-19'un şimdiye kadar ABD borsasında volatiliteyi en çok etkileyen enfeksiyon hastalı̆̆1 olduğunu belirtmiş, Onali (2020) ise pandemi ile ABD borsalarının değer kaybettiğini ve VIX korku endeksinin yükseldiğini söylemiştir. BIST pay piyasası açısından da durum farklı gelişmemiştir. Sonuç olarak COVID-19 perspektifinde elde ettiğimiz bulgular BİST sektör endekslerinde özellikle 11 Mart ve sonrasında negatif getirilerin görüldüğünü raporlayan Kılıç (2020)'ın bulgularılyla örtüşmektedir.

Açığa satış yasağı ile fiyat marjı ve devre kesici tetikleme oranı düzenlemeleri bir arada değerlendirildiğinde olay tarihlerinden önceki ve sonraki günlerde pozitif ve/veya negatif kümülatif anormal getiriler edilebildiği görülmüştür. Dolayısıyla $\mathrm{H}_{0}$ hipotezi reddedilirken $\mathrm{H}_{1}$ hipotezi kabul edilmiştir. Yatırımcılar açısından ele alındığında olağanüstü gelişmelerin yaşandığ1 dönemlerde sermaye piyasalarında getiri volatilitesinin artabileceği, pay senetlerinin fiyatlarında sert dalgalanmaların meydana gelebileceği ve fiyat marjlarındaki oynaklı̆ın normal sınırların dışına çıkabileceği gözardı edilmeden pozisyon alınması gerektiği unutulmamalıdır. Nihai olarak, ortaya konulan verilere göre incelenen olaylar ve dönemler çerçevesinde BIST pay piyasasının yarı güçlü formda etkin olmadığı, alınan tedbirlerin kısmen amaçlanan çıktıları verdiği bulgularına ulaşılmışır.

\section{Etik Beyan}

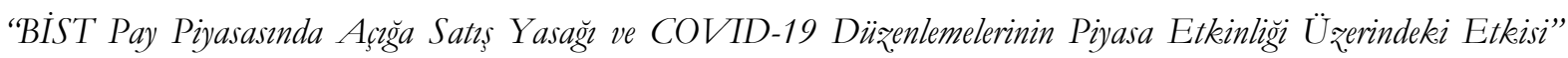
başlıklı çalışmanın yazım sürecinde bilimsel, etik ve alıntı kurallarına uyulmuş; toplanan veriler üzerinde herhangi bir tahrifat yapılmamıs ve bu çalışma herhangi başka bir akademik yayın ortamına değerlendirme için gönderilmemiştir. Bu araştırmada hazır veri seti kullanıldığı için etik kurul kararı zorunluluğu taşımamaktadır.

\section{Kaynakça}

Abdioğlu, N. ve Aytekin, S. (2019). Açığa satış fiyatının belirleyicileri: Borsa İstanbul Mali Endeksi (XUMAL) Üzerinde Bir Uygulama. İnsan ve Toplum Bilimleri Arasttrmalar Dergisi, 8(3), 2081-2098. doi: https://doi.org/10.15869/itobiad.568523

Al-Awadhi, A. M., Alsaifi, K., Al-Awadhi, A. ve Alhammadi, S. (2020). Death and contagious infectious diseases: Impact of the COVID-19 virus on stock market returns. Journal of Behavioral and Experimental Finance, 27, 1-4. doi: https://doi.org/10.1016/j.jbef.2020.100326

Alfora, L., Chari, A., Greenland, A. N. ve Schott, P. K. (2020). Aggregate and firm level stock returns during pandemics, in real time. NBER Working Paper Series, No 26950. Erişim adresi: https://www.nber.org/papers/w26950

Ashraf, B. N. (2020). Stock markets' reaction to COVID-19: Cases or fatalities? Research in International Business and Finance, 54, 1-7. doi: https://doi.org/10.1016/j.ribaf.2020.101249

Autore, D. M., Billingsley, R. S. ve Kovacs, T. (2011). The 2008 short sale ban: Liquidity, dispersion of opinion, and the cross-section of returns of US fnancial stocks. Journal of Banking and Finance, 35, 2252-2266. doi: 10.1016/j.jbankfin.2011.01.026

Aygören, H. ve Uyar, S. (2007). İstanbul Menkul Kyymetler Borsası'nda (IMKB) Denetim görüşlerinin hisse senedi getirileri üzerindeki etkisi. IMKB Dergisi, 9(36), 33-51. Erişim adresi: https://www.borsaistanbul.com/datum/imkbdergi/IMKB_Dergisi_Turkce36.pdf

Baker, S., Bloom, N., Davis, S. J., Kost, K., Sammon, M. ve Viratyosin, T. (2020). The unprecedented stock market reaction to COVID-19. NBER Working Paper Series, No 26945. Erişim adresi: https://www.nber.org/papers/w26945.pdf

Baidoo, K. B. (2019). The Effect of short selling on financial market volatilities. European Journal of Business Science and Technologies, 5(2), 218-228. doi:http://dx.doi.org/10.11118/ejobsat.v5i2.183

Baklacı, H. F., Süer, Ö. ve Yelkenci, T. (2016). A closer insight into the causality between short selling trades and volatility. Financial Researcb Letters, 17, 48-54. doi:http://dx.doi.org/10.1016/j.frl.2016.01.007 
Basdas, U. ve Oran, A. (2014). Event studies in Turkey. Borsa Istanbul Review, 14(3), 167-188. doi:https://doi.org/10.1016/j.bir.2014.03.003

Beber, A. ve Pagano, M. (2013). Short-selling bans around the world: Evidence from the 2007-09 Crisis. Journal of Finance, 68(1), 343-381. doi:https://doi.org/10.1111/j.1540-6261.2012.01802.x

Boehmer, E. ve Wu, J. (2013). Short selling and the price discovery process. The Review of Financial Studies, 26(2), $287-$ 322. doi:https://doi.org/10.1093/rfs/hhs097

Bohl, M. T., Reher, G. ve Wilfling, B. (2016). Short selling contraints and stock return volality: Empirical evidence from the German stock market. Economic Modelling, 58, 159-166. doi:http://dx.doi.org/10.1016/j.econmod.2016.05.025

Bris, A., Goetzman, W. N. ve Zhu, N. (2007). Efficiency and the bear: Short sales and markets around the world. Journal of Finance, 62, 1029-1079. doi: https://doi.org/10.1111/j.1540-6261.2007.01230.x

Cankaya, S., Eken, H. M. ve Ulusoy, V. (2012). The impact of short selling on intraday volatility: Evidence from the Istanbul stock exchange. International Research Journal of Finance and Economics, 93, 202-212. Erişim adresi: https://papers.ssrn.com/sol3/papers.cfm?abstract_id=2193861

De Vito A. ve Gomez, J. P. (2020). Estimating the COVID-19 cash crunch: Global evidence and policy. Journal of Accounting and Public Policy, 39(2), 1-14. doi:https://doi.org/10.1016/j.jaccpubpol.2020.106741

Ding, W., Levine, R., Lin, C. ve Xie, W. (2020). Corporate 1mmunity to the Covid-19 pandemic. NBER Working Paper Series, No 27055. Erişim adresi: http://www.nber.org/papers/w27055

Ebrahimnejad, A. ve Hosainzade, S. (2019). Short-sale constraints and stock price informativeness. Global Finance Journal, 40, 28-34. doi: https://doi.org/10.1016/j.gfj.2018.11.002

Erol, A. F. ve Aytekin, S. (2018). Borsa İstanbul Pay Piyasası şirketlerinin bedelsiz sermaye artırımı duyurularının hisse senedi getirileri üzerindeki etkisinin değerlendirilmesi. Mehmet Akif Ersoy Üniversitesi İktisadi ve İdari Bilimler Fakültesi Dergisi, 5(3), 898-912. doi: 10.30798/makuiibf.439219

Goodell, J. W. ve Huynh, T. L. D. (2020). Did congress trade ahead? Considering the Reaction of US industries to COVID-19. Finance Research Letters, 101578. doi: https://doi.org/10.1016/j.frl.2020.101578

Hekimoglu, M. H. ve Tanyeri, B. (2011). Stock market reactions to mergers of non-financial Turkish firms. İktisat İsletme ve Finans, 26(308), 53-70. doi: 10.3848/iif.2011.308.3095

Henry, O. T. ve McKenzie, M. (2006). The impact of short selling on the price-volume relationship: Evidence from Hong Kong. Journal of Business, 79(2), 671-91. doi: 10.2139/ssrn.407711

Jung, C. S., Kim, W. ve Lee, D. W. (2013). Short selling by individual investors: destabilizing or price discovering? Pacific-Basin Finance Journal, 21, 1232-1248. doi: https://doi.org/10.1016/j.pacfin.2012.09.001

Ji, Q., Zhang, D. ve Zhao, Y. (2020). Searching for Safe-haven assets during the COVID-19 pandemic. International Review of Financial Analysis, 71, 1-10. doi:https://doi.org/10.1016/j.irfa.2020.101526

Kılıç, Y. (2020). Borsa İstanbul'da COVID-19 (Koronavirüs) Etkisi. Journal of Emerging Economies and Policy, 5(1), 6677. Erişim adresi: https://dergipark.org.tr/tr/download/article-file/1132865

Kim, J., Kim, J., Lee, S. K. ve Tang, (Rebecca) L. (2020). Effects of epidemic disease outbreaks on financial performance of restaurants: Event study method approach. Journal of Hospitality and Tourism Management, 43, 3241. doi:10.1016/j.jhtm.2020.01.015

Li, Z., Lin, B., Zhang, T. ve Chen, C. (2018). Does short selling improve stock price efficiency and liquidity? Evidence from a natural experiment in China. The European Journal of Finance, 24(15), 1350-1368. doi:https://doi.org/10.1080/1351847X.2017.1307772

Liu H, Manzoor A., Wang C, Zhang L. ve Manzoor, Z. (2020). The COVID-19 outbreak and affected countries stock markets response. International Journal of Environmental Research and Public Health, 17(8), 1-19. doi:10.3390/ijerph17082800

Marsh, Ian W. ve Payne, R. (2012). Banning short sales and market quality: The UK's experience. Journal of Banking and Finance, 36, 1975-1986. doi:http://dx.doi.org/10.1016/j.jbankfin.2012.03.005

Mertzanis, C. (2015). Short selling regulation, return volatility and market volatility in the athens exchange. Studies in Economics and Finance, 34 (1), 143-164. doi: 10.1108/SEF-06-2015-0157

Miller, E. M. (1977). Risk, uncertainty, and divergence of opinion. Journal of Finance, 32(4), 11511168. doi:https://doi.org/10.1111/j.1540-6261.1977.tb03317.x

Mishra, A. (2005). An empirical analysis of market reaction around the bonus issues in India. Indian Institute of Management Working Paper, No. 2005-10. Erişim Adresi: https://ssrn.com/abstract=733043 or http://dx.doi.org/10.2139/ssrn.733043

Morck, R., Yeung, B. ve Yu, W. (2000). The information content of stock markets: Why do emerging markets have synchronous stock price movement. Journal of Financial Economics, 58(1), 215-260. doi: 10.1016/S0304405X(00)00071-4

Ofek, E. ve Richardson, M. (2003). DotCom mania: The rise and fall of internet stock prices. The Journal of Finance, 58 (3), 1113- 1137. doi:https:/ / doi.org/10.1111/1540-6261.00560

Onali, E. (2020). Covid-19 and stock market volatility. SSRN Working Paper. Erişim adresi: https://papers.ssrn.com/sol3/papers.cfm?abstract_id=3571453

Sansa, N. A. (2020). The impact of the COVID - 19 on the financial markets: Evidence from China and USA. Electronic Research Journal of Social Sciences and Humanities, 2(2), 29-39. Erişim adresi: https://papers.ssrn.com/sol3/papers.cfm?abstract_id=3562530 
Sharif, A., Aloui, C. ve Yarovaya, L. (2020). COVID-19 pandemic, oil prices, stock market, geopolitical risk and policy uncertainty nexus in the US economy: Fresh evidence from the wavelet-based approach. International Review of Financial Analysis, 70, 1-9. doi:https://doi.org/10.1016/j.irfa.2020.101496

Sobac1, C., Sensoy, A. ve Ertürk, M. (2014). Impact of short selling activity on market dynamics: Evidence from an emerging market. Journal of Financial Stability, 15, 53-62. doi:https://doi.org/10.1016/j.jfs.2014.08.010

Suresha, B. ve Chandrashekara, B. (2016). Market efficiency around bonus, stock split and rights 1ssue announcement-evidence from India. Journal of Economics and Sustainable Development, 7(11), 71-79. Erişim adresi: https://www.semanticscholar.org/paper/Market-Efficiency-around-Bonus\%2C-Stock-Split-and-E2\%80\%93Suresha-Chandrashekara/b5118f785f643db10180b3345cf85f9fa0555446

Yilmaz, A. K. ve Gulay, G. (2006). Dividend policies and price-volume reactions to cash dividends on the stock market: Evidence from the Istanbul stock exchange. Emerging Markets Finance and Trade, 42(4), 19-49. doi:https://doi.org/10.2753/REE1540-496X420402

Zeren, F. ve Hizarc1, A. E. (2020). The 1mpact of Covid-19 coronavirus on stock markets: Evidence from selected countries. Muhasebe ve Finans Incelemeleri Dergisi, 3(1), 78-84. doi: 10.32951/mufider.706159

Zhang, D., Hu, M. ve Ji, Q. (2020). Financial markets under the global pandemic of Covid-19. Finance Research Letters, In Press. doi: https://doi.org/10.1016/j.frl.2020.10152

\section{EXTENDED ABSTRACT}

BIST-100 index increased to over 120.000 points in January 2020. However, after the air strikes against Turkish soldiers by the regime forces in Idlip on February 27, the index, which was 115,000 the previous day, retreated to 105,000 levels within two days. At this point, the CMB announced the ban on short selling in BIST equity markets on February 28. While the short sale ban regulation continues, the concern caused by the COVID-19 outbreak in the world markets continued to be followed by both investors and the legal authority. Reporting of first coronavirus case in Turkey on March 11 and declaration of a pandemic virus by WHO the same day caused uneasiness in all the markets and in BIST. Borsa İstanbul introduced new rates on March 13, announcing that it will change the daily price change limits with the circuit breaker trigger rate in the share market on March 12. The main purpose of this regulation is to reduce volatility and prevent losses that may occur with possible panic sales in the market. The BIST-100 index closed on March 13 at 95,000 points with an increase of approximately 2,000 points compared to the previous day. Despite the circuit breaker and price margin restrictions with the ongoing short selling ban, the downward trend continued until March 23. On March 23, the BIST-100 index closed at 84,000 points, the lowest level seen since early January. Due to the COVID-19 epidemic, the successive asset purchase and monetary expansion steps from the major central banks have been found in financial markets due to the closure of their economies. As these developments began to be priced in BIST, the index rose to 100,000 thousand levels again at the end of April.

In this study, firstly, the effects of the short sale ban on BIST-30 companies' shares, which were decided to be implemented by BIST on the equity markets on February 28, 2020, were examined. For the short selling ban introduced in the BIST equity market on February 28, 2020, it was observed that a statistically significant negative abnormal return could be obtained 3 days $(+3)$ and 5 days $(+5)$ after the event date. Mean abnormal returns and cumulative average abnormal returns were also observed negatively the same days. When looking at cumulative abnormal returns, it is understood that statistically significant negative cumulative abnormal returns can be obtained only 5 days (+5) after the event date. Therefore, the short selling ban regulation could not prevent the index and shares from depreciation. Moreover, prohibition of short selling may have negative effects on price fluctuations and on price formation. Çankaya et al. (2012) and Sobac1 et al. (2014) revealed that short selling constraints reduce volatility in BIST. However, Beber and Pagano (2013), Miller (1977), Morck et al. (2000), Bris et al. (2007) stated that short selling bans affect the liquidity negatively, the shares are overvalued with the arbitrage withdrawals from the market and thus the price efficiency in the market is deteriorated. In this period, the fact that the share prices subject to futures contracts in the BIST Futures and Options Market are lower than the spot prices are based on similar reasons. Negative returns in the BIST share market during this period coincide with the findings of Ofek and Richardson (2003) that the short selling ban applied during the DotCom crisis in the USA reduced stock returns.

Secondly, 13 March 2020 is accepted as another event day. Both the WHO declared a pandemic for the virus outbreak on 11 March 2020 and the decisions taken by the BIST General Directorate after the virus outbreak were effective in the selection of this event date. BIST General Directorate decreases the price margin applied to the shares traded in all of the BIST Stars and BIST Main groups to $10 \%$, reduce 
the rate of circuit breaker triggering applied to the shares traded in all the BIST Star Market and Main Market groups to 5\%, and traded in the BIST Stars and the BIST Main. After the circuit breaker applied in the shares, it is decided to apply the order collection time as 30 minutes and started to apply them on 13 March 2020. When the short selling ban and price margin and circuit breaker trigger rate arrangements are evaluated together, it is seen that positive and/or negative cumulative abnormal returns can be obtained in the days before and after the event dates. When it comes to investors, it should be kept in mind that during periods of extraordinary developments, the price fluctuations in capital markets may increase and fluctuations in price margins may go beyond normal limits. Ultimately, it has been found that the BIST share market is not effective in a semi-strong form within the framework of the events and periods analyzed according to the data revealed, and that the measures taken partially achieved its purpose. 